\title{
Cybernetyczne spojrzenie na prawo - przyczynek do historii cybernetyki prawniczej
}

\begin{abstract}
Zrozumienie umożliwia zastapienie działań nieracjonalnych lub bezradności przez działania racjonalne.
\end{abstract}

Na wstępie wypada poczynić kilka zastrzeżeń. Po pierwsze, artykuł niniejszy ze względu na swoje ramy, nie może pomieścić prezentacji, choćby najbardziej pobieżnej, poglądów wszystkich cybernetyków, którzy wypowiadali się na temat prawa (i prawników) oraz analogicznych poglądów prawników na cybernetykę (i cybernetyków), i to nawet gdyby ograniczyć się do polskiej cybernetyki i polskiej nauki prawa. Zdecydowano się więc na przedstawienie rozwoju myśli dotyczącej panowania /władania /rządzenia/ kierowania/ sterowania etc. oraz prawa. Zaprezentowano poglądy na tematy prawnicze Norberta Wienera, który uchodzi za twórcę cybernetyki jako osobnej dziedziny. Następnie, po lapidarnej wzmiance o cybernetyce radzieckiej, przeniesiono rozważania na grunt polski. Kolejność omawiania poglądów poszczególnych autorów i ilość miejsca im poświęcona nie stanowią przejawu ich hierarchizacji. Starano się wyważyć z jednej strony reprezentatywność twórczości poszczególnych autorów, z drugiej zaś strony oryginalność tejże twórczości. Po drugie, autor koncentruje się na niekomputerowych, „niemaszynowych” przejawach cybernetyki prawniczej. Po trzecie, choć autor niniejszego artykułu zajmuje się wykorzystywaniem cybernetyki na gruncie prawa (poświęcił tym zagadnieniom m.in. sporą część swojej rozprawy doktorskiej¹), to tekst niniejszy napisany jest raczej w duchu antykwarycznym niż merytorycz-

\footnotetext{
${ }^{1}$ M.H. Górny, Optymalizacja czynności kryminalistycznych, niepublikowana dysertacja doktorska napisana pod kierunkiem dr hab. Anny Koziczak, prof. ndzw. UKW i obroniona na Wydziale Prawa, Administracji i Ekonomii Uniwersytetu Wrocławskiego w dniu 8 XII 2016 r.
} 
nym (aby użyć rozróżnienia często przywoływanego na wykładach przez logika Bogusława Wolniewicza ${ }^{2}$ ), to jest oceny przydatności poszczególnych koncepcji z perspektywy teraźniejszości zostały w tekście ograniczone do minimum. Nie oznacza to, iż abstrahuje całkowicie od jakichkolwiek ocen, zwłaszcza od wykazywania błędów i niedoskonałości, które mogłyby być (i częstokroć były) zauważane w czasach, w których poszczególne koncepcje były publikowane. $\mathrm{Z}$ tych też względów terminy „prawny” i ,prawniczy” używane będą w niniejszym tekście zamiennie. Rzecz jasna autor zdaje sobie sprawę z różnic między tymi terminami na gruncie tradycyjnej nauki prawa. Co więcej, autor dostrzega potrzebę podjęcia refleksji nad wyróżnieniem cybernetyki prawnej (cybernetyki prawa?) i cybernetyki prawniczej. Roboczo rzecz ujmując - ta pierwsza zajmowałaby się stosowaniem osiągnięć cybernetyki w projektowaniu i badaniu prawa (cybernetyka łączyłaby się z nauką prawa, stawała jej częścią, ,wnikała do istoty” prawa), ta druga zaś używaniem narzędzi cybernetycznych w praktyce prawniczej (cybernetyka byłaby w tym ujęciu czymś obcym, zewnętrznym, wykorzystywanym przez naukę prawa, ale się z nią niemieszającym). Jednakowoż są to zagadnienia merytoryczne, a nie antykwaryczne, i jako takie domagają się osobnego omówienia.

Od starożytności poszukiwano dróg wiodących do ulepszenia prawa - w tym do jego lepszego zorganizowania - a także sposobów skuteczniejszego zdobywania i sprawowania władzy. Choć prawo jest niewątpliwie jednym z ważniejszych sposobów sprawowania władzy (i sterowania społeczeństwem w ogóle), to rozważania o sterowaniu i rozważania o prawie prowadzone były w dużej mierze poniekąd osobno. ${ }^{3} \mathrm{~W}$ państwach starożytnego Bliskiego Wschodu prawo poczęto

${ }^{2}$ Wolniewicz używa tego rozróżnienia $\mathrm{w}$ stosunku do sposobów naukowego zajmowania się filozofią. Vide choćby wystąpienie „Melioryzm Leibnitza” wygłoszone na konferencji „Poza czasem i przestrzenią" poświęconej Gottfriedowi Wilhelmowi Leibnizowi, zorganizowanej przez Prof. J. Hołówkę i dr B. Dziobkowskiego w dniach 7-8 czerwca w sali im J. Brudzińskiego w Pałacu Kazimierzowskim [za:] https://www.youtube.com/watch?v=tp_q_oLW66o [dostęp 14 II 2017 r.].

${ }^{3}$ Idzie o to, że zorganizowane uprawianie naukowej, instrumentalnej polityki prawa rozpoczęło się dosyć późno. Andrzej Malinowski (Wstęp do badań cybernetycznych w prawoznawstwie, Warszawa 1977, s. 15) powołuje się na Leona Petrażyckiego. Petrażycki zdaniem Malinowskiego jest „często uważany za protoplastę współczesnej polityki prawa [...]”. Andrzej Kisza (Model cybernetyczny powstawania i działania prawa, Prace Wrocławskiego Towarzystwa Naukowego seria A nr 133, Wrocław 1970, s. 6) chwali dominujące u Petrażyckiego myślenie przyczynowo-skutkowe. Przy okazji można nadmienić, iż socjocybernetyk Józef Kossecki często cytował i wysoko cenił prace Petrażyckiego (na przykład: Podstawy nowoczesnej nauki porównawczej o cywilizacjach. Socjologia porównawcza cywilizacji, Katowice 2003, s. 191). Wcześniej zastawiano się przede wszystkim nad słusznością prawa z punktu widzenia ideologii wyznawanej przez klasę autoryzującą normy, a działania sterownicze skupiały się na wysokości kar i wykrywalności przypadków łamania prawa, a nie na skuteczności sterowniczej samego sposobu konstruowania prawa, wpływie występowania norm w uwikłaniu z innymi na skuteczność odbierania i respektowania tychże etc. 
kodyfikować i ogłaszać wystawiając na tablicach. Wiedza o kierowaniu społeczeństwem trzymana była w tajemnicy, przekazywana w zamkniętych kręgach, „wydawana jedynie na receptę rządu” - aby posłużyć się określeniem z okresu Mikołajewskiego ${ }^{4}$. Były to zresztą przejawy znacznie szerszego zjawiska - użytkowego, często wyłącznie instrumentalnego traktowania wiedzy, które sprawiło, że choć rozwijały się na Wschodzie technika i sztuka, to powstanie nauki zawdzięczamy dopiero Hellenom. Dopiero bowiem w świecie helleńskim rozpoczęło się poszukiwanie wiedzy z miłości do prawdy, szukanie prawdy dla samej prawdy; zaczęto podejmować próby wnikania $\mathrm{w}$ istotę pewnych zjawisk zamiast li tylko rejestrowania wiedzy o ich możliwych skutkach, poczęto wiedzę organizować, a nie tylko gromadzić, rozmaite koncepcje zaczęły być poddawane krytycznemu osądowi i publicznej debacie, a nie jedynie przekazywane i rozszerzane (poprzez nawarstwianie) za zamkniętymi drzwiami. ${ }^{5} \mathrm{~W}$ zdobywaniu wiedzy, obok funkcji użytkowych, pojawiły się też funkcje „czysto” poznawcze; zaczęto poznawać rzeczywistość, a nie tylko jej pozory. Ślepa empiria rozjaśniona została blaskiem podejścia logiczno-analitycznego. Naprzeciw kłębowiska wschodniej magii wyrósł dumny gmach zachodniej nauki.

Rozważania Hellenów nie ominęły również sfery panowania, istoty władzy i sposobów rządzenia, a nawet szerzej - sterowania ${ }^{6}$. Rzymianie z kolei,

${ }^{4}$ Generał Leoncjusz Wasiliewicz Dubelt - zastępca szefa III Oddziału Kancelarii Osobistej Jego Cesarskiej Mości i cenzor - zanotował w swoim dzienniku: „w Rosji uczeni winni postępować jak aptekarze: wydawać wiedzę jedynie na receptę rządu”. Zob.: W. Śliwowska, Mikołaj I i jego czasy, Warszawa 1965, s. 41 [za:] J. Kossecki, Podstawy nowoczesnej nauki porównawczej o cywilizacjach. Socjologia porównawcza cywilizacji, op.cit, s. 174.

5 „U Greków spotykamy coś, co oni pierwsi wprowadzili w pracę naszych myśli, a mianowicie, wszędy przenikające przekonanie, że każde stwierdzenie nasze o tyle bywa słuszne, o ile bywa uzasadnione". Zob.: T. Zieliński, Świat antyczny a my. (Osiem wykładów, wygłoszonych na uniwersytecie w Petersburgu w roku 1901), Zamość 1922, s. 112. Prawdziwa debata naukowa może odbywać się tylko między istotami, których przekonanie jest możliwe, które posiadają zdolność ulegania argumentom rozumowym. Uznanie jakichś tez nastąpić winno po udowodnieniu ich prawdziwości, po odwołaniu się do świadomej warstwy intelektualnej, nie zaś za pomocą żywiołowego nastrajania (ibidem, s. 112-115). „Tak, raz jeszcze powtarzam: uległość wobec argumentów zasadnych, owa rękojmia wolności umysłowej i postępu umysłowego - to najcenniejsza spuścizna filozofii antycznej, jako utworu literackiego" (ibidem, s. 115). Cywilizacja ateńska była pierwszą cywilizacją opartą na prymacie pojęcia prawdy obiektywnej nad ,prawdami” formalnymi (stereotypami prawdy). J. Kossecki, Podstawy nowoczesnej nauki porównawczej o cywilizacjach. Socjologia porównawcza cywilizacji, op.cit., s. 162, 163.

${ }^{6}$ „Grecja przekazała nam i w wykładach teoretycznych i w zastosowaniu praktycznym zasady polityki w jak najszerszym znaczeniu słowa [...]”. (T. Zieliński, op.cit., s. 130). ,już od dawna starano się traktować procesy zarządzania w sposób naukowy. Może się przy tym wydawać zadziwiające, że idea ta, znana już starożytnym Grekom, nie była kontynuowana [...]”. (M. Mazur, Cybernetyka a zarządzanie, Ministerstwo Spraw Wewnętrznych, Departament Szkolenia i Wydawnictw, do użytku wewnętrznego, Warszawa 1969, s. 7). W pewnym sensie stoicki dogmat wszechświatowej 
posiadając własne oryginalne osiągnięcia w sferze instytucji władzy publicznej oraz prawodawstwa (nie tylko cywilnego, o czym często się zapomina), podnieśli prawo na niespotykany dotychczas, jakościowo wyższy poziom prawo staje się wyodrębnioną, samodzielną i pełnoprawną dyscypliną naukową. Mimo regresu, jaki nastąpił w wielu dziedzinach wraz z upadkiem antycznego Rzymu, prawo rozwijało się dzięki ośrodkom kościelnym. Za sprawą Świętej Inkwizycji pojawiły się traktaty, które omawiały i analizowały już nie tylko samo prawo, ale metody skutecznego wykrywania i zwalczania naruszeń tegoż, a zatem: pojawiły się pierwsze podręczniki śledcze. Nie brakowało traktatów, w których snuto filozoficzne i teologiczne rozważania nad pochodzeniem władzy i powinnościami podmiotów władających i władzy poddanych. Pisano książki zawierając praktyczne wskazania dla osób kierujących różnymi instytucjami, w tym całymi państwami. Jednakowoż brakowało dzieł zajmujących się naukowo samym sterowaniem jako osobnym, wyodrębnionym zjawiskiem. Próbą wypełnienia tej luki jest cybernetyka, a więc nauka o sterowaniu, jak stanowi jej najprostsza i najlepsza definicja. ${ }^{7}$ Sterowanie to „wywieranie pożądanego wpływu na dowolne zjawiska" ${ }^{8}$. Wpływ pożądany to „działanie wywołane przez źródło motywacji [...]”. Choć cybernetyka jako osobna dziedzina naukowa pojawiła się stosunkowo późno, to rodowód terminu cybernetyka (i samych rozważań sterowniczych, o czym wspomniano powyżej) jest starożytny.

Słowo cybernetyka pochodzi od greckiego kybernetiken, które oznacza umiejętność kierowania, sterowania. Kybernetiken pochodzi zaś od kyberan, co oznacza kierowanie, kontrolowanie. ${ }^{10}$ Początkowo wyrazy te odnoszone były jedynie do sterowania okrętem, później w formie przenośni zaczęto je odnosić i do ludzi, przez co uległy uogólnieniu. Właściwie, prawidłowym brzmieniem polskiej nazwy tej nauki winna być ,kybernetyka”, jako że w polskich nazwach greckiego pochodzenia nie zastępuje się k przez c. „Nazwa „cybernetyka” upowszechniła się wcześnie za sprawą francuskojęzycznych (vide: omówiona w dalszej części tekstu książka Trentowskie-

sympatii (w znaczeniu współzależności obiektów, wzajemnego ich powiązania, wpływie zmiany w jednym na inne) można uznać za wczesną formę rozważań, które z czasem doprowadziły do powstania pojęcia sprzężeń zwrotnych.

${ }^{7}$ M. Mazur, Cybernetyczne zagadnienie przebiegu życia, „Pomiary Automatyka Kontrola. Miesięcznik Naukowo-techniczny” Zeszyt 3, Rok IX, marzec 1963, s. 97. NB! W przypisie na tej stronie podano, iż zagadnienia poruszane w artykule Mazura „były tematem szeregu odczytów wygłoszonych przez autora w ostatnich latach [...]".

8 Ibidem. Józef Kossecki - uczeń Mariana Mazura - podczas wykładu otwartego, który wygłosił 11 V 2010 w Warszawie zaproponował, aby definiować sterowanie jako wywieranie celowego wpływu na określone zjawiska.

9 M. Mazur, Cybernetyczna teoria układów samodzielnych, Warszawa 1966, s. 12.

${ }^{10}$ M. Mazur, Terminologia techniczna, Warszawa 1961, s. 178. 
go), a następnie anglojęzycznych publikacji, i to pomimo iż w języku rosyjskim występuje „kibiernietika”. ${ }^{11}$ Od słowa kybernetes (gr. sternik) pochodzą zaś takie nazwy jak gubernator (stąd biorą się sformułowania o „sterniku nawy państwowej” etc.). Platon w „Gorgiaszu” przypisuje Sokratesowi następujące zdanie: „Cybernetyka chroni od największych szkód nie tylko dusze, lecz również ciała i dobytek”. Matematyk i fizyk André Marie Ampère w wydanym w 1834 Eseju o filozofii nauki, albo analitycznym przedstawieniu naturalnego podziału wiedzy ludzkiej nazywa cybernetyką część polityki zajmującą się metodami rządzenia ${ }^{12}$. W podobnym jak Ampère znaczeniu używał słowa cybernetyka filozof i pedagog Bronisław Ferdynand Trentowski w wydanej w Poznaniu w 1843 książce Stosunek filozofii do cybernetyki, czyli sztuki rządzenia narodem. Rzecz treści politycznej ${ }^{13}$. Według Trentowskiego cybernetyka prowadzi do uchwycenia „politycznej prawdy dla teraźniejszości naszej. Prawda objawia się już tu w swym żywostanie, t. j. in actu, czyli w umiejętnej praktyce, i wraca co chwila w historyzm. Polityka w ogóle opisuje tu swe filozoficzne doskonałości koło i przechodzi do swej realizacyi w naszym czasie. Cybernetyka to trudna sztuka rządzenia narodem"14. Cybernetykę wiązał Trentowski z praktyką i z teraźniejszością, a ponadto raczej ze sferą decyzyjną niż poznawczą. ${ }^{15}$ Podjęcie się omówienia zagadnień cybernetycznych uważał za swój obowiązek patriotyczny $^{16}$, a nawet religijny ${ }^{17}$.

Za twórcę cybernetyki jako osobnej dziedziny naukowej uchodzi matematyk Norbert Wiener, a jego wydana po raz pierwszy w 1948 książka Cybernetics or

${ }^{11}$ Ibidem.

${ }_{12}$ M. Mazur, Cybernetyka a zarzqdzanie, op.cit., s. 7.

${ }_{13}$ B. F. Trentowski, Stosunek filozofii do cybernetyki, czyli sztuki rządzenia narodem. Rzecz treści politycznej, Poznań 1843.

14 Ibidem, s. 9.

15 Trentowski usiłował podkreślić dobitnie te właściwości cybernetyki w całym swoim traktacie. Celem egzemplifikacji można przytoczyć fragment z ostatniej strony: „Filozofia, uprawiając polityczną boskość swojego czasu, i pokazując, jak dziś być powinno, lecz nie jest, wychowuje najbliższą przyszłość, a Cyberneta rządzi teraźniejszością. Dziś jest cybernetyka rozkazującą panią, a filozofia także jej służebnicą, ale dzisiejsza filozofia jest panią cybernetyki jutrzejszej [...] cyberneta nie rozwikłuje ludzkości, lecz wiedzie ją za rękę [...]" (ibidem, s. 194).

16 „Polityka nabiera w naszych czasach co dzień więcej rzeczywistej wartości i ogólnego znaczenia. Najnowsza filozofia niemiecka, jak powszechnie wiadomo, stałą się zgoła istną polityką. Czem jest polityka dla Polaków, nie potrzebujmy nadmieniać. Wszakże rzuca się w jej ramiona tak skrzętnie nawet młodzież szkolna. - Nie wątpimy, iż równie w kraju jak w emigracji znajdą się głębocy i prawdziwi politycy, co zaszczyt, oraz pożytek przynieść mogą Ojczyźnie. Jednak pod względem teoretycznym polityka jest u nas bardziej może, niż inne więcej i mniej ważne umiejętności, zaniedbana”. Ibidem, s.1.

17 Przykładowo na stronie 21 Trentowski nazywa politykę ,ziemską madonną, człowieka-rodzicą”. Cały traktat napisany jest w duchu mesjanistycznym i obfituje w religijne porównania. Trentowski starał się mesjanizm racjonalnie uzasadnić oraz naukowo podbudować i zorganizować. 
Control and Communication in the Animal and the Machine ${ }^{18}$ uważana jest za pierwszą publikację naukową z tego zakresu. W wydanej po raz pierwszy w 1950 roku książce The Human Use of Human Beings. Cybernetics and Society Wiener stwierdza, że nazwę cybernetyka wymyślił sam, a dopiero później dowiedział się o wcześniejszych przypadkach używania tego terminu ${ }^{19}$.

Prawo, jak już nadmieniono, jest jedną z metod sterowania społeczeństwem. Coraz powszechniejsze i intensywniejsze wykorzystywanie tej metody (obejmowanie przez normy prawne coraz to nowych dziedzin i wypieranie $\mathrm{z}$ nich innych norm) zbiegło się w czasie z powstaniem i rozwojem cybernetyki. Nic więc dziwnego, iż cybernetycy wcześnie zainteresowali się zagadnieniami prawnymi, a następnie prawnicy cybernetyką.

Już Wiener w Cybernetyce czyli sterowaniu w zwierzęciu i maszynie wspominał o prawie. Uznał on prawo za jeden z czynników, które jego zdaniem uniemożliwiają skuteczne działanie mechanizmów homeostazy społecznej ${ }^{20} \mathrm{~W}$ większych wspólnotach. Jako przykład podał on unikanie przez antyspołeczne osobniki potępienia społecznego za pomocą wytaczania procesów o zniesławienie. ${ }^{21}$ Prawdą jest, że wytaczanie procesów o ochronę dóbr osobistych i wnoszenie prywatnych aktów oskarżenia o zniesławienie często nie służy obronie honoru uczciwych ludzi, ale jest narzędziem terroru w rękach ludzi pozbawionych honoru, za to posiadających pieniądze lub wpływy; jest często argumentem siły w rękach osób, którym brakuje argumentów merytorycznych, przejawem pogardy dla prawdy, etyki i wolności słowa etc. To jednak nie usprawiedliwia zbyt daleko idących uproszczeń. Prawo jest jednak elementem społecznych procesów homeostatycznych, zwłaszcza w dużych społecznościach - wśród większej liczby ludzi łatwiej jest się ukryć i operować osobnikom nieetycznym, zorganizowana reakcja prawna może takie jednostki eliminować bądź przynajmniej ograniczać im pole manewru; w dużych a jednocześnie zatomizowanych społecznościach sankcja rozsiana może mieć wobec nich ograniczoną skuteczność.

${ }_{18}$ Polskie wydanie na podstawie drugiego, poprawionego i rozszerzonego wydania angielskiego: N. Wiener, Cybernetyka czyli komunikacja i sterowanie w zwierzęciu i maszynie, Warszawa 1971.

19 N. Wiener, Cybernetyka a spoleczeństwo, Warszawa 1961, s. 15, 16.

${ }^{20}$ Wiener nie definiuje homeostazy społecznej. We wcześniejszych fragmentach książki (Norbert Wiener, Cybernetyka czyli komunikacja i sterowanie w zwierzęciu i maszynie, os.cit., s. 152, 153) omawia (choć nie definiuje wprost) homeostazę osobniczą. Daje też odwołania m.in. do Waltera B. Cannona, a więc fizjologa, który wprowadził pojęcie homeostazy. Homeostaza (od greckich słów homois - podobny i stasis, czyli trwanie) to stan równowagi funkcjonalnej organizmu. Wiener stwierdza, że w podręcznikach cybernetyki będzie trzeba omówić i wyjaśnić homeostazę znaczenie lepiej niż on to czyni w swoim wstępnym dziełku (ibidem, s. 153).

${ }^{21}$ Ibidem, s. 206. 
W książce Cybernetyka $i$ społeczeństwo poświęcił Wiener zagadnieniom prawnym osobny rozdział (oraz fragmenty innych rozdziałów). „Problemy prawa należy uznać za należące do cybernetyki i teorii porozumiewania się: są to problemy określonych i powtarzalnych metod panowania nad pewnymi sytuacjami krytycznymi" 22 . Wiener dzieli prawo na dwie zasadnicze grupy problemów: cele i sposoby ich osiągania. ${ }^{23}$ Stawia on przed prawem kilka celów, w których osiągnięciu cybernetyka może wydatnie pomóc. Należą do nich: ujednolicenie linii orzeczniczej, osiągniecie klarowności i jednoznaczności norm ustalanych przez prawo, uproszczenie prawa, uwzględnianie obyczajów panujących w dziedzinie, która ma być uregulowana etc. Wiener ma wyraźny problem z rozróżnieniem etyki i prawa, definiuje to ostatnie jako „kontrolę etyczną" ${ }^{24}$. Stoi to zresztą w sprzeczności z podawanym w książce stwierdzeniem, że wiele praw kłóci się z pojęciem słuszności. ${ }^{25}$ Kierując się kryterium zagrożeń dla procesu komunikowania się wyróżnił Wiener dwie odmiany języka: zwykły (w którym głównym zagrożeniem jest entropia i związana z nią możliwość utraty informacji) i prawniczy (gdzie istnieje zagrożenie celowego zniekształcenia informacji). „Zwykła rozmowa prowadzona w celach porozumiewawczych, gdzie głównym przeciwnikiem jest entropijna skłonność natury, nie ma czynnego wroga, świadomego swoich celów. Z drugiej strony, dyskurs typu prawniczego, jaki spotykamy w sądach, ciałach ustawodawczych i tak dalej, napotyka na znacznie groźniejszego oponenta, którego świadomym celem jest ograniczenie, a nawet zniszczenie sensu wypowiedzi”'26. Rozróżnienie między nieścisłościami w zeznaniach (wyjaśnieniach) wynikającymi z przyczyn naturalnych (niespostrzeżenie czegoś, zapomnienie czegoś, nieudolne przekazanie tego, co się zapamiętało), a tymi, które mają charakter selektywny, wynikają z celowego działania, ma ogromne znaczenie z punktu widzenia nauk sądowych. Błędem jest jednak uznawanie z góry wszelkich debat prawniczych za z gruntu zakłamane. Wielką zaś naiwnością byłoby uznanie, iż we wszelkich pozaprawniczych dyskusjach nie występują żadne zagrożenia dla przekazu informacji poza entropijnymi. „Powiedzmy to tak: pierwszym obowiązkiem prawa bez względu na to, jakie są jego dalsze obowiązki - jest wiedzieć, czego chce"27. Choć z twierdzeniem tym należy się zgodzić, to jednak wypada też zauważyć, iż Wiener sam nie do końca wie, czego chce od prawa (i nie tylko od prawa) i jak je rozumie lub nie potrafi (nie chce?) swoich poglądów przedstawić w spójny i klarowny sposób, co zilustrowane zostało na powyżej zaprezentowanych przy-

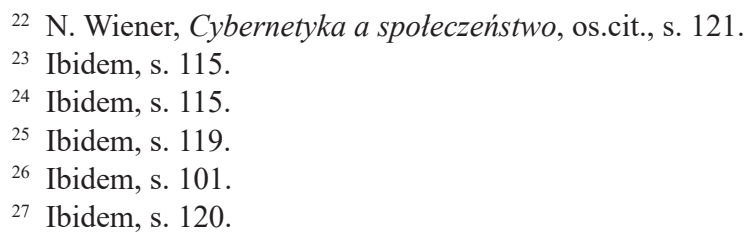


kładach. Tymczasem warto dbać o klarowność zarówno przy rozwiązywaniu pewnego problemu, jak i przy prezentacji rozwiązania. Świetnie oddają to słowa wybitnego polskiego filozofa: „Myśl tak, abyś dobrze wiedział, o czym myślisz; mów tak, abyś nie tylko dobrze wiedział, o czym mówisz, ale też tak, abyś miał pewność, że ten, do którego mówisz, słuchając cię uważnie, będzie myślał o tym samym co i ty" 28 .

Lektura książek Wienera i spojrzenie na nie z dzisiejszej perspektywy skłania do ciekawych refleksji z zakresu socjologii nauki. Jakkolwiek by nie oceniać zbyt generalizujących, nazbyt uproszczonych i słabo uargumentowanych sądów Wienera na temat prawa (ale też i na kilka innych dziedzin, żeby wymienić choćby ekonomię), to książki Wienera stanowią przełom naukowy, a sam Wiener nie tylko zainicjował oficjalnie nową dyscyplinę naukową, ale też wniósł niemały dorobek do kilku „starszych” dziedzin. Niemniej jednak jego dwie cytowane w niniejszym artykule książki (podobnie jak i niektóre inne jego publikacje, z którymi piszący te słowa miał okazję się zapoznać) nie spełniają elementarnych wymogów, jakie stawia się obecnie w III RP przed publikacjami naukowymi. Można rzecz jasna spekulować, czy Norbert Wiener, gdyby żył w dzisiejszej Polsce, dostosowałby się do wymogów, czy też po prostu nie stworzyłby niczego przełomowego (możliwe są wszakże i warianty pośrednie).

W Polsce po raz pierwszy naukowymi zagadnieniami cybernetycznymi zajął się w 1942 roku teleelektryk Marian Mazur ${ }^{29}$. Niestety rękopis jego pracy spłonął w powstaniu warszawskim, w którym brał on zresztą udział (choć był oficerem saperów, to służył w intendenturze). Po wojnie nowy okupant uznawał cybernetykę za reakcyjną pseudonaukę burżuazyjną, stanowiącą narzędzie kapitalistycznego imperializmu. ${ }^{30}$ Zorganizowana nagonka na cybernetykę zaczęła się w latach 1952-1953. „Jednakże rzeczywiste ideologiczne niebezpieczeństwo cybernetyki dla sowieckiej doktryny polegało na tym, że chodziło tu o pewną bardzo ogólną teorię, stworzoną w świecie zachodnim, a pretendującą, słusznie czy niesłusznie, do roli mathesis universalis, najbardziej zgeneralizowanego sposobu ujęcia zjawisk dynamicznych; lecz do tej roli pretendował także marksizm-leninizm"31. Ataki na cybernetykę zostały ukrócone pod naciskiem wpływowych wojskowych, którzy zdawali sobie sprawę z jej użyteczności. ${ }^{32}$ Dopiero po odwilży cybernetyka mogła być uprawiana w Związku Radzieckim, a następnie również w pozostałych państwach Ukła-

${ }^{28}$ K. Ajdukiewicz, Pozanaukowa działalność Tadeusza Twardowskiego, „Ruch Filozoficzny”, t. XIX, nr 1-2 (1959), s. 31 [za:] J.J. Jadacki, Metodologia i semiotyka. Idee - metody - problemy, Warszawa 2010, s. 269.

${ }^{29}$ M. Mazur, Cybernetyczna teoria układów samodzielnych, os.cit., s. 7.

${ }^{30}$ Krótki słownik filozoficzny pod redakcją M.M. Rozentala i S.F. Judina, Warszawa 1955, s. $76,77$.

${ }^{31}$ L. Kołakowski, Główne nurty marksizmu. Część III Rozkład, Wydawnictwo, Poznań 2000, s. 168.

32 Ibidem, s. 168, 169. 
du Warszawskiego. Uczeni radzieccy szybko zabrali się za nadrabianie zaległości, a następnie za konkurowanie z cybernetykami amerykańskimi. Niektóre z radzieckich prac dotyczących cybernetyki zostały przethumaczone i wydane po polsku - nie zabrakło wśród nich prac dotyczących zastosowania cybernetyki w naukach społecznych i humanistycznych. ${ }^{33}$ Niestety, według wiedzy autora, żadna z licznych publikacji radzieckich z cybernetyki prawa nie została wydana po polsku.

Gdy po 1956 zaczęły docierać do Polski publikacje cybernetyczne z Zachodu, Marian Mazur doszedł pod wpływem ich lektury do dwóch wniosków. Po pierwsze: jego opracowana $\mathrm{w}$ warunkach konspiracji teoria układów samodzielnych nadal wyprzedzała powstałe $\mathrm{w}$ komfortowych warunkach prace zachodnie. Po wtóre: czeka go ogrom pracy, aby stworzyć spójną a jednocześnie uniwersalną teorię, której zastosowania nie będą ograniczone do nauk ścisłych. Wielu innych uwierzyło, że dzięki cybernetyce możliwym stało się dokonanie szybkiego i radykalnego przełomu nie tylko w nauce i technice, ale też w gospodarce i ,życiu codziennym". Entuzjazm w stosunku do cybernetyki ogarnął z czasem decydentów politycznych i dziennikarzy, a za ich sprawą i część społeczeństwa. Jak napisano we wprowadzeniu „Od redakcji” do jednej z cytowanych już książek cybernetycznych: ,zainteresowanie cybernetyką jest ogromne, mówi się nawet o modzie na cybernetykę"34. Entuzjazm ten okazał się dla samej cybernetyki szkodliwy - wiązał się z wygórowanymi oczekiwaniami, naiwnymi wyobrażeniami, małą a często błędną wiedzą - doprowadził do marnotrawienia środków na najbardziej efektowne, ale nie efektywne badania cybernetyczne, a w końcu poskutkował pokaźnym rozczarowaniem i odwróceniem się od cybernetyki. „W ciągu trzydziestu lat istnienia cybernetyka stała się czymś tak powszechnie znanym, że trudno byłoby znaleźć człowieka ze średnim wykształceniem, który by o niej nie słyszał. Niestety, ta optymistyczna ocena dotyczy s $\nmid$ y s z e $n$ i a o cybernetyce; na pytanie, czym jest i co wnosi, choćby przybliżoną odpowiedź zdołałaby dać tylko niewielka liczba ludzi, a sens cybernetyki wymyka się często nawet rozumieniu specjalistów korzystających z niej w pracy zawodowej" ${ }^{35}$. Cybernetyka jest często błędnie utożsamiana z robotyką lub naukami komputerowymi. Największe, a przynajmniej najbardziej spektakularne, osiągnięcia poczyniła cybernetyka właśnie w tych obszarach (i na nich napotkała też najmniejszy opór). Również cybernetyka prawnicza często błędnie utożsamiana jest z komputerami - wszyst-

${ }^{33}$ Przykładowo: B.W. Biriukow, J.S. Geller, Cybernetyka w naukach humanistycznych, Wrocław 1983. Rosyjskie thumaczenie Cybernetyki... Wienera ukazało się w ZSRR w 1958 roku. Dość wcześnie wydano również inne podstawowe dzieła z zakresu cybernetyki. Polski czytelnik może się o tym łatwo przekonać przeglądając wykazy literatury do polskich wydań radzieckich cybernetyków. Przykładowo: B.N. Puszkin, Psychologia i cybernetyka, Warszawa 1976, s. 212, 213.

${ }^{34}$ M. Mazur, Cybernetyka a zarzadzanie, op.cit., s. 5.

${ }^{35}$ M. Mazur, Społeczne znaczenie cybernetyki, „Nowe Drogi” nr 5, 1980, s. 152. 
kie te modne dziś cyberzagrożenia, cyberprzestępczości, centra bezpieczeństwa cybernetycznego etc. Warto przy tym pamiętać, że na styku cybernetyki i informatyki prawniczej osiągnięto bardzo wiele. Zdarzali się (i zdarzają nadal) uczeni zajmujący się obiema dziedzinami, czego dobitnym przykładem był Franciszek Studnicki ${ }^{36}$. Informatyka była też wcześniej traktowana znacznie szerzej. ${ }^{37}$

Pionierem polskiej cybernetyki prawniczej (a przy okazji również informatyki prawniczej) był wspomniany wcześniej Franciszek Gizbert-Studnicki - początkowo karnista (doktorat w 1939), później cywilista (dysertacje habilitacyjne w 1949 nieobroniona ze względu na zbytnią prokapitalistyczność, kolejna, tym razem obroniona, w 1955), następnie teoretyk i filozof prawa. Pierwszą jego publikacją, w której poruszył możliwość zastosowania podejścia cybernetycznego w prawie była $Z$ teorii promulgacji $i^{38}$ Następnie przyszedł czas m.in. na Przepływ wiadomości o normach prawa ${ }^{39}$ i Cybernetykę i prawo ${ }^{40}$. Ta ostatnia książka stanowi omówienie i ulepszenie koncepcji omawianych we wcześniejszych publikacjach (jest to też przyczyną skupienia się właśnie na niej). ${ }^{41}$ Pierwsze zdanie we „Wprowadzeniu” zamieszczonym w Cybernetyce i prawie brzmi: „Słowo cybernetyka kojarzy się zwykle tylko z maszynami”42. Dalej pisze Studnicki: „zastosowanie cybernetyki $\mathrm{w}$ tych dyscyplinach naukowych, których przedmiotem jest człowiek i społeczności ludzkie, są - i zapewne pozostaną zawsze - o wiele skromniejsze"43. Studnicki dzieli cybernetykę prawa na dwie grupy problematyk, które jego zdaniem nie pozostają ze sobą w bliższym związku, a mianowicie na: problematykę maszyn, które miałby rozstrzygać spory prawne, oraz na problema-

${ }^{36}$ Zob.: F. Studnicki, Nowe środki udostępniania treści prawa pozytywnego jednostce, „Zeszyty Naukowe Uniwersytetu Jagiellońskiego", Prace Prawnicze nr 81, 1978.

${ }^{37}$ M. Owoc, M. Zieliński, Elementy informatyki, Poznań 1976. Za sprawą Owoca w książce, poza opisami podstaw programowania komputerowego, pojawiają się także omówienia teorii informacji (zarówno ilościowej C.E. Shannona, jak i jakościowej M. Mazura), a także elementy teorii gier. O tym, jak szeroko można traktować informatykę prawniczą, świadczą słowa Jerzego Wróblewskiego: „Nie jest tutaj niezbędne precyzyjne określenie informatyki prawniczej, które wymagałoby zaproponowania określonej definicji syntetycznej, konwencjonalnie wyznaczającej zakres tego terminu. Dla naszych potrzeb wystarczy ogólne stwierdzenie, że chodzi o wszelką informację, która jest używana w dziedzinie nauk prawnych oraz w praktyce prawniczej”. (J. Wróblewski, Informatyka prawnicza - możliwości zastosowania cybernetyki, „Państwo i Prawo” 1/1971, z. 3-4, s. 639)”.

${ }^{38}$ F. Studnicki, Z teorii promulgacji [w:] Zagadnienia prawa karnego i teorii prawa. Ksiega pamiatkowa ku czci prof. W. Woltera, Warszawa 1959 za: F. Studnicki, Cybernetyka i prawo, Warszawa 1969, s. 2 (nota na wewnętrznej części okładki).

${ }^{39}$ F. Studnicki, Przepływ wiadomości o normach prawa, „Zeszyty Naukowe Uniwersytetu Jagiellońskiego", Prace Prawnicze z. 32, Kraków 1965.

${ }^{40}$ F. Studnicki Cybernetyka i prawo, op.cit.

${ }^{41}$ Ibidem, s. 7.

${ }^{42}$ Ibidem, s.9.

${ }^{43}$ Ibidem. 
tykę badań nad funkcjonowaniem porządku prawnego. ${ }^{44}$ Choć Studnicki zajął się w cytowanej książce drugą z wymienianych problematyk, to widać jak ciężko jest się czasem uwolnić od technicznych przejawów cybernetyki. Studnicki potraktował oddziaływanie przy pomocy norm prawa jako sterowanie. ${ }^{45}$

Franciszek Studnicki zajął się cybernetyką za sprawą zainteresowania procesami przepływania wiadomości o normach prawa. Wiadomości te podzielił na trzy grupy: wiadomości podstawowe (które winna posiadać każda jednostka funkcjonująca w społeczeństwie), wiadomości minimum rolowego (których przyswojenie jest wymagane od osób zajmujących określone stanowiska, sprawujących określone funkcje społeczne) i wiadomości ad hoc (potrzebne przy zajmowaniu się określonymi sprawami, zwłaszcza nietypowymi). ${ }^{46}$ Zainteresowania Studnickiego nie ograniczały się bynajmniej do standardowych, sformalizowanych procesów publikowania i ogłaszania aktów normatywnych, ale obejmowały szerokie spektrum zarówno występujących wówczas, jak i dopiero przez niego postulowanych i projektowanych sposobów docierania norm do adresatów. Dobry przykład stanowią mechanizmy orientacji pośredniej ${ }^{47}$, a więc „mechanizmy społeczne, których działanie umożliwia jednostce zdobycie pewnego stopnia orientacji, co do wymagań stawianych przez prawo i co do oferowanych przez prawo możliwości, bez podejmowania wysiłku koniecznego przy bezpośrednim zdobywaniu wiadomości o normach"48. Do najważniejszych mechanizmów orientacji pośredniej zalicza Studnicki: orientację podług wzorców pragmatycznych, orientację aksjologiczną, orientację podług stereotypów instytucji prawnych oraz orientację naśladowczą. Mechanizmy orientacji podług wzorców pragmatycznych to ,przyjęte w określonych zbiorowościach ludzkich sposoby zachowania się w sytuacjach typowych, tj. scharakteryzowanych przez pewne powtarzające się rysy. Każda jednostka ludzka zdobywa znajomość owych wzorów, jako część potocznej wiedzy praktycznej, nabywanej przez siebie w procesie uspołecznienia"49. Orientacja aksjologiczna związana jest z wartościami wyrażanymi przez porządek prawny. „Wyobrażenia o tych wartościach buduje sobie jednostka na podstawie swoich doświadczeń, czerpanych w takich sytuacjach, w których wyraźnie ujawniają się stawiane przez ten porządek, wymagania. Wyobrażenia te dają jednak bardzo ogólny - a tym samym wielce zawodny - typ orientacji" ${ }^{50}$. Orientacja podług stereotypów instytucji prawnych polega na kierowaniu się przy podejmowaniu

\footnotetext{
44 Ibidem, s. 9, 10.

45 Ibidem, s. 52-74.

46 Ibidem, s. 76.

47 Ibidem, s. 126-136.

48 Ibidem, s. 126, 127.

49 Ibidem, s. 127.

50 Ibidem, s. 131.
} 
decyzji w sferze prawnej uproszczonymi wyobrażeniami instytucji prawnych. Ten typ orientacji ma zastosowanie zwłaszcza w sytuacjach typowych. Orientacja naśladowcza ma zastosowanie zwłaszcza w sytuacjach zmiennych i polega na naśladowaniu w sferze prawnej zachowań innych osób, zwłaszcza tych, które są odpowiedzialne za obronę praworządności. Studnicki twierdził, iż w stosunku do twierdzeń cybernetycznych podejście analityczne, jak i empiryczne są równoprawne. ${ }^{51}$

Nieco inaczej do zagadnień cybernetyki prawa podchodził adwokat i teoretyk prawa Andrzej Kisza, dziś bardziej pamiętany jako historyk adwokatury i działacz samorządu adwokackiego. Kisza w swojej monografii habilitacyjnej postanawia, podobnie jak Studnicki, zając się „niemaszynowymi” zastosowaniami cybernetyki w prawie, ale w przeciwieństwie do Studnickiego uznaje on całkowity prymat podejścia empirycznego: „Osiąganie bezpośrednich wyników praktycznych z pomocą cybernetyki musi się opierać na badaniach empirycznych. Dlatego próby stosowania cybernetyki do nauk prawniczych mają, jak w socjologii prawa, tendencję i do matematyczności, i do empirii" "52. Prace nad swoją rozprawą miał rozpocząć Kisza niezależnie, dopiero później zapoznając się z pozycjami innych autorów - przed oddaniem książki do druku zapoznał się on m.in. z nieopublikowanymi wówczas jeszcze pracami Studnickiego i Wróblewskiego. ${ }^{53} \mathrm{Za}$ dwa główne zastosowania cybernetyki w prawie uznawał Kisza: „1. posługiwanie się cybernetyką w poznawaniu rzeczywistości, od której zależy norma, 2. ujęcie w kategorie cybernetyczne całego mechanizmu powstawania i działania norm prawnych" 54 . Podczas pisania Modelu cybernetycznego powstawania i dziatania prawa Kisza, niegdyś akademik-cywilista, od dawna opuścił już mury uczelni i zawodowo zajął się praktyką. Jako czynny adwokat przywiązywał Kisza wielką wagę do uwzględniania w swoich modelach rozmaitych podmiotów biorących udział nie tylko w stanowieniu prawa, ale też w jego stosowaniu.

Rozprawa Kiszy charakteryzuje się sporą liczbą wzorów matematycznych (i „,matematykopodobnych”) oraz schematów blokowych. Te ostatnie szczególnie rzucają się w oczy; na nich przedstawiane są zależności występujące w różnych dziedzinach i aspektach prawa. Wielką wagę w całej dysertacji przywiązywał Kisza do zagadnień relacji między prawem stanowionym a moralnością, na omówienie tych zagadnień przeznaczył też osobny rozdzia ${ }^{55}$. Innym ważnym problemem, któremu poświęcono w Cybernetycznym modelu powstawania i działania prawa

${ }^{51}$ F. Studnicki (głos w dyskusji) [w:] J. Jaroń, F. Studnicki, S. Gerstman, J. Goldstein, J. Latuśkiewicz, B. Jewsiewicki, Koreferaty $i$ dyskusja [w:] Zagadnienia cybernetyki we współczesnej biologii, „Zeszyty Problemowe Kosmosu” Zeszyt 14 (Materiały Konferencji Problemowej Polskiego Towarzystwa Przyrodników im. Kopernika 3 kwietnia 1965), Warszawa 1968, s. 69, 70.

52 A. Kisza, Model cybernetyczny powstawania i działania prawa, op.cit, s. 11.

${ }^{53}$ Ibidem, s. 9-11.

54 Ibidem., s. 20.

55 Ibidem, s. 113-126. 
sporo uwagi, były zakłócenia. ${ }^{56}$ Kisza podzielił je na zakłócenia zewnętrzne i zakłócenia wewnętrzne, które nazwał szumami. Szumy podzielił z kolei na szumy naturalne (czyli powstające „niezależnie od przewidywań i woli [...]” ustawodawcy) i sztuczne (,które mogą służyć władzom za narzędzie, w szczególności inne niż zwykła droga prawna, w celu osiągnięcia pewnych zamierzonych skutków w społeczeństwie"). ${ }^{57} \mathrm{~W}$ monografii habilitacyjnej Kiszy dostrzeżono ogromne zagrożenie, jakie stanowi zjawisko narastania liczby przepisów i ilości norm prawnych mających służyć eliminacji szumów, które same tworzą nowe szumy, co w konsekwencji prowadzi do powstania swoistej hierarchii norm przeciwszumowych. ${ }^{58}$ Działa tu mechanizm sprzężenia zwrotnego dodatniego rozbieżnego. Warto więc wszelkie zmiany projektować $\mathrm{w}$ ten sposób, aby z góry uniknąć powstawania szkodliwych szumów albo choćby zminimalizować ich liczbę.

I tu można by się pokusić o przemyślenia z zakresu socjologii nauki. Habilitowanie się z innej specjalności niż ta, z której obroniło się rozprawę doktorską, nie jest (na szczęście) traktowane jako coś nadzwyczajnego, jednak przewody habilitacyjne osób niebędących zawodowymi akademikami i dziś są nieczęste, wówczas stanowiły zaś prawdziwą rzadkość. Wykaz piśmiennictwa zawiera kilkadziesiąt pozycji ${ }^{59}$, ale w pracy, z wyjątkiem wprowadzenia, odwołania do innych autorów należą do prawdziwej rzadkości i z reguły ograniczają się do krótkiej wzmianki w nawiasie. Superrecenzentem w przewodzie habilitacyjnym prawnika Andrzeja Kiszy był Marian Mazur - teleelektryk (przed wojną), elektrotermik (po wojnie, do lat 60.), a następnie cybernetyk i prakseolog. W 1986 ukazała się książeczka Kiszy Teoria dowodów sądowych w świetle modelu cybernetyczno-prawnego, którą autor niniejszego artykuł zna jedynie z recenzji. ${ }^{60}$ Opierając się na niej można stwierdzić, iż recenzowane dziełko stanowi kontynuację wątków rozpoczętych w książce Model cybernetyczny powstawania i działania prawa i obfituje w częste do niej odwołania. Charakteryzuje się też podobnym katalogiem wad i zalet: „ogólne wrażenie, jakie czynią te konstrukcje, wykresy, wzory - wrażenie sporej dozy dowolności i odwrotnie - proporcjonalnej miary sprecyzowania" ${ }^{61}$. Recenzent zwraca też uwagę, że choć same przekształcenia matematyczne są niewątpliwie poprawne, to problem mogą stanowić dane wejściowe, których określenie

${ }^{56}$ Ibidem, s. 52.

57 Ibidem.

58 Ibidem, s.. 53, 54.

${ }^{59}$ Ibidem, s. 159-162.

${ }^{60}$ Marian Cieślak, Andrzej Kisza: „Teoria dowodów sądowych w świetle modelu cybernetyczno-prawnego”, Warszawa 1986, s. 58: [recenzja], „Palestra” 34/8-9 (392-393), 1990, s. 74-77 za: http://bazhum.muzhp.pl/media//files/Palestra/Palestra-r1990-t34-n8_9\%28392_393\%29/Palestra-r1990-t34-n8_9\%28392_393\%29-s74-77/Palestra-r1990-t34-n8_9\%28392_393\%29-s74-77. pdf [dostęp: 14.02.2017].

${ }^{61}$ Ibidem, s. 75. 
będzie mieć z reguły charakter intuicyjny. ${ }^{62}$ Naturalnie, zmniejsza to zalety takiego podejścia, ale ich nie niweczy. W recenzji zwrócono też uwagę (i chwalono) rozważania Kiszy na temat „prawdy” formalnej ${ }^{63}$ oraz przesłuchania, zwłaszcza w kontekście pytań niedozwolonych ${ }^{64}$.

Logik Andrzej Piotr Malinowski poświęcił cybernetyce swoją niepublikowaną pracę doktorską ${ }^{65}$, a następnie cytowaną już dysertację, której recenzentami wydawniczymi byli Studnicki i Wróblewski ${ }^{66}$ We Wstępie do badań cybernetycznych $w$ prawoznawstwie skupił się Malinowski na automatyzacji procesów stosowania prawa; zasadnicza część monografii jest mocno sformalizowana i zmatematyzowana, silna jest tu tendencja do algorytmizacji. Malinowski zajął się więc „maszynowymi” zastosowaniami cybernetyki w prawie, które w swoich książkach cybernetycznych otwarcie pomijali Studnicki i Kisza (choć ten pierwszy zajął się w innych publikacjach także informatyką prawniczą, o czym wyżej napomknięto). W przeciwieństwie do książki Model cybernetyczny powstawania i działania prawa, w dysertacji Wstę do badań cybernetycznych w prawoznawstwie sporo jest w zasadniczej części pracy odwołań do innych autorów. Ze względu na aspekty „maszynowe” książka Malinowskiego nie będzie szerzej omawiana. Jednak warto się do monografii Malinowskiego odwołać w dwóch jeszcze kwestiach. Pierwszą z nich jest proponowany podział publikacji cybernetyczno-prawnych na: 1. omawiające zagadnienia natury filozoficzno-moralnej związane z wprowadzeniem idei cybernetyki do prawa, 2. opisujące badania nad językiem tekstów prawnych i jego kodowaniem oraz nad przepływem informacji prawnej, 3. dotyczące cybernetycznego modelowania zjawisk prawnych, 4. omawiające zastosowania cybernetyki w kryminalistyce i statystyce prawniczej ${ }^{67}$ Ponieważ w niniejszym tekście nie wspomniano jeszcze o pozycjach, które należą wyłącznie albo w przeważającej swej części do czwartej kategorii, to zostanie to poniżej pokrótce nadrobione. Warto też mieć na względzie iż, jak słusznie zauważa Malinowski, większość prac trudno jest zaszeregować wyłącznie do jednej z tych kategorii ${ }^{68}$, choć, jak się zdaje, najłatwiej wyróżnić pod tym względem prace „czysto” kryminalistyczne. Druga z tych kwestii związana jest z ramami niniejszego artykułu (i z czasem jego autora ${ }^{69}$ ). Czytelników zainteresowanych omówieniem pub-

62 Ibidem.

${ }^{63}$ Ibidem, s. 75, 76.

${ }^{64}$ Ibidem, s. 76.

${ }^{65}$ A. Malinowski, Zastosowanie pojęć i metod cybernetycznych do modelowania procesów stosowania norm prawa, 1969 [za:] A. Malinowski Wstęp do badań cybernetycznych w prawoznawstwie, op.cit., s. 20.

${ }^{66}$ A. Malinowski Wstęp do badań cybernetycznych w prawoznawstwie, op.cit., s. 9.

${ }^{67}$ Ibidem, s. 23, 24.

${ }^{68}$ Ibidem, s. 25.

${ }^{69}$ Marian Mazur - najwybitniejszy polski cybernetyk - kończy zasadniczą część swojej najbardziej znanej (co nie znaczy bynajmniej, że najważniejszej czy najlepszej) książki Cybernetyka 
likacji z zakresu cybernetyki prawniczej do drugiej połowy lat siedemdziesiątych - tych zwłaszcza, które w bieżącym tekście nie zostały opisane - pozwala sobie autor odesłać do „Wprowadzenia”" ${ }^{{ }^{0} 0}$ oraz do wykazu piśmiennictwa ${ }^{71}$ zawartych w książce Malinowskiego. Poniżej zaś zaprezentowane zostaną - w bardzo ogólnym niestety zarysie - poglądy polskich naukowców-nieprawników zajmujących się cybernetyką na zagadnienia prawnicze, prace poświęcone kryminalistycznym zastosowaniom cybernetyki oraz najnowsze publikacje z cybernetyki prawniczej.

Marian Mazur stworzył polską szkołę cybernetyki - oryginalną, odrębną, samodzielną terminologicznie i metodologicznie szkołę cybernetycznego myślenia i działania. W jej ramach powstało wiele teorii i koncepcji, które mogą być niezwykle użyteczne na gruncie prawniczym. Do największych cybernetycznych osiągnięć samego Mazura należą: cybernetyczna teoria układów samodzielnych (zwanych w późniejszych publikacjach systemami autonomicznymi), cybernetyczna teoria decyzji, jakościowa teoria informacji i cybernetyczna teoria charakteru. W książce Cybernetyczna teoria układów samodzielnych ${ }^{72}$, poza omówieniem tytułowych układów samodzielnych, opisano również i typy układów mniej zorganizowanych; teoria ta może być przydatna przy projektowaniu i badaniu zarówno konstrukcji prawnych, jak i podmiotów odpowiedzialnych za stanowienie i stosowanie prawa. Cybernetyczna teoria decyzji ${ }^{73}$ może być przydatna zarówno w aspekcie preskryptywnym (ustalanie zaleceń odnośnie racjonalnego podejmowania określonych decyzji), jak i deskryptywnym (poznawanie, jak w rzeczywistości, „na co dzień” wygląda podejmowanie decyzji w sferze prawnej). Teorię tę udoskonalił autor niniejszego artykułu. ${ }^{74}$ Jakościowa teoria informacji ${ }^{75}$ może być wykorzystywana zarówno przy analizie informacji zdobywanych przez rozmaite służby etc., jak i lepszym poznawaniu i projektowaniu samych tekstów prawnych i prawniczych. Mazur w „Przedmowie” do Jakościowej teorii informacji napisał, że jego teoria ,pozwala wyrazić proces informowania ogólnym wzorem logiczno-matematycznym, którego analiza ujawnia wszelkie możliwe rodzaje informowania"76. Jakościowa teoria informacji jest dobitnym przykładem samodzielności polskiej szkoły cybernetyki. ${ }^{77}$ Józef Kossecki - najwybitniejszy uczeń

\footnotetext{
i charakter słowami Hamleta: „Mógłbym wiele rzeczy powiedzieć, gdybym miał czas” (Marian Mazur, Cybernetyka i charakter, Warszawa 1976, s. 427). Te słowa towarzyszyły autorowi podczas pisania niniejszego artykułu.

${ }^{70}$ A. Malinowski, Wstęp do badań cybernetycznych w prawoznawstwie, op.cit., s. 11-32.

${ }^{71}$ Ibidem, s. 179-183.

${ }^{72}$ M. Mazur, Cybernetyczna teoria układów samodzielnych, op.cit.

${ }_{73}$ M. Mazur, Cybernetyka a zarządzanie, op.cit., s. 71-81 oraz 97-159, zwłaszcza zaś s. 97-114.

${ }^{74}$ M. H. Górny, Optymalizacja czynności kryminalistycznych, op.cit., s. 232-247.

${ }_{75}$ M. Mazur, Jakościowa teoria informacji, Warszawa 1970.

${ }^{76}$ Ibidem, s. 12.

77 Jak podkreślono w słowie „Od Wydawcy” Mazur „przyjmuje w książce całkowicie oryginal-
} 
Mariana Mazura - uznawał jakościową teorię informacji za największe osiągnięcie swojego mistrza (opinię tę podziela autor niniejszego tekstu) oraz stworzył jej uogólnioną wersję - ogólną jakościową teorię informacji. ${ }^{78}$ Teoria informacji w ujęciu Kosseckiego jest, jak się zdaje, prostsza w przyswojeniu przez „statystycznych" prawników i łatwiejsza do bezpośredniego zastosowania na gruncie teorii prawa. Odnoszą się do niej twierdzenia jakościowej teorii informacji (która jest w niej zawarta), z tym że Mazur traktował informowanie jak fizykalne transformacje, a Kossecki uwzględniał również bardziej abstrakcyjne ${ }^{79}$ podejście.

Cybernetyczna teoria charakteru, najpełniej opisana przez Mazura w cytowanej książce „Cybernetyka i charakter”, jest najbardziej znaną (co nie znaczy, że najlepiej zrozumianą) i najczęściej rozwijaną z teorii Mazura; najwięcej jest też przypadków wykorzystania właśnie tej teorii na gruncie nauk społecznych i humanistycznych, najwięcej jest też jej przeinaczeń i innych zniekształceń, błędnych interpretacji, zbyt uproszczonych $\mathrm{i}$ instrumentalnie wykorzystywanych prezentacji etc. Do jej głównych zalet należy zaliczyć podział cech charakteru na sztywne i niesztywne, a także przewidywanie nieuchronnych zmian, jakie następują pod wpływem czasu. Na gruncie prawniczym cybernetyczna teoria charakteru może być wykorzystywana przede wszystkim do określana charakteru osób występujących w sytuacjach relewantnych prawnie i związanych z tym charakterem implikacji (dobieranie osób posiadających pożądany charakter do zajmowania poszczególnych stanowisk służbowych, dobieranie sposobu przesłuchania w zależności od charakterów przesłuchiwanych i przesłuchujących, dobieranie informatorów w zależności od cech charakteru sprzyjających przekazywaniu rzetelnych informacji, ocenianie wiarygodności wersji zdarzeń z uwzględnieniem charakteru osób w tej sytuacji występujących etc.). Wykorzystać ją jednak można również choćby do określania charakteru zwie-

ną metodę prowadzenia rozważań. Nie podejmuje nawet próby poszukiwania definicji informacji, a co więcej, nie odwołując się wcale do teorii informacji, rozpoczyna rozważania od analizy uogólnionego toru sterowniczego, a w szczególności od jego elementów składowych i ich transformacji. $\mathrm{W}$ związku z tym podane $\mathrm{w}$ toku tej analizy twierdzenia wynikają z przekształceń formalnych i nie podlegają weryfikacji na podstawie takich czy innych twierdzeń ze znanej dotychczas w nauce teorii informacji. Dopiero pojęciom wyodrębnionym w tych rozważaniach Autor przypisuje w dalszej części książki takie terminy, jak np. komunikat, kod, informacja i in., proponując zastosowanie opracowanej przez siebie analizy do procesów informacyjnych i wywodząc dalsze twierdzenia dotyczące tych procesów. Mówiąc jednym zdaniem, nie z teorii informacji wywodzą się rozważania w tej książce, lecz do niej prowadzą" (ibidem, s. 9, 10).

78 J. Kossecki, Metacybernetyka, nakładem własnym Autora, Kielce-Warszawa 2005, s. 24-33.

79 Abstrakcyjność przekształceń informacyjnych rzecz jasna nie uchybia temu, iż do przekazania, odebrania i zapisania informacji, nawet abstrakcyjnych, potrzebna jest nadal energomateria, można jednak teoretycznie obniżyć jej wielkość poniżej progu czułości nawet najbardziej dokładnych urządzeń pomiarowych i wówczas z punktu widzenia fizykalnego praktycznie ją pominąć. 
rząt wykorzystywanych w pracy rozmaitych służb, a w przyszłości ewentualnie do określania charakteru sztucznej inteligencji będącej autonomem (sztucznie stworzonym systemem autonomicznym).

Opisywanie możliwych zastosowań Mazurowskich teorii wykracza daleko poza ramy niniejszego artykułu, tym bardziej że, jak już nadmieniono na wstępie, ma on w założeniu charakter bardziej antykwaryczny niż merytoryczny. Dorobek Mazura był jednak wykorzystywany na gruncie prawniczym i wciąż przedstawia sobą wielką wartość pod kątem dalszego wykorzystania. Stąd też za stosowne uznano zamieszczenie wcześniejszej charakterystyki głównych teorii Mazura, a także dalsze odwołanie się do jego dorobku w trzech jeszcze aspektach. Chodzi mianowicie o pokazanie głównych wyróżników Mazurowskiej cybernetyki, wspomnienie o bezpośrednim zaangażowaniu Mazura na gruncie prawniczym oraz o prawnikach, którzy odnosili się do dorobku Mazura.

Marian Mazur uznawał cybernetykę za naukę analityczną ${ }^{80}$ i porównywał ją do matematyki: „cybernetyk, podobnie jak matematyk, operuje pojęciami abstrakcyjnymi, analizuje je, dochodzi do określonych wniosków za pomocą operacji sformalizowanych. W świecie rzeczywistym cybernetyk nie szuka dowodów swoich twierdzeń, lecz ilustracji otrzymanych wyników. Dzięki temu ma on w rozpatrywanych przez siebie zagadnieniach kompletną wiedzę o tym, co jest możliwe"81. Ojciec polskiej szkoły cybernetyki odszedł od metody analogii (choć od niej rozpoczął, jeszcze przed wojną, swe rozważania sterownicze) i związanego z nią modelowania, na rzecz metody generalizacji i związanego z nią tworzenia wzorców. Metoda analogii polega na doszukiwaniu się wspólnych cech różnych tworów. Ma ona taki mankament, iż aby wnosić o jakichś właściwościach z podobieństwa między dwoma tworami bądź jakimś tworem i jego modelem, „trzeba uprzednio to podobieństwo udowodnić na podstawie tych okoliczności, a to prowadzi do błędnego koła. Zazwyczaj stosowanie tych metod sprowadza się do wskazania podobieństwa pewnych cech, ażeby na tej podstawie wysuwać przypuszczenia o podobieństwie również innych cech"82. Stosowana przez Mazura metoda generalizacji „polega na wprowadzeniu koncepcji tworu ogólniejszego, w stosunku do którego rozmaite twory mogłyby być traktowane jako przypadki szczególne, w związku z tym o ich cechach można wnosić z cech tworu ogólniejszego"\$3. Metoda ta posiada tę zaletę, że po „ustaleniu założeń oparta na niej teoria może (a nawet powinna) być opracowana bez wprowadzania ogniw dowodowych z obserwacji rzeczywistości. Niegdyś, w zastosowaniu tej metody, fakt,

\footnotetext{
${ }^{80}$ M. Mazur, Cybernetyka a zarzadzanie, op.cit., s. 93.

${ }^{81}$ Ibidem, s. 93, 94.

${ }^{82}$ Marian Mazur, Cybernetyczna teoria uktadów samodzielnych, op.cit., s. 13.

${ }^{83}$ Ibidem.
} 
że jeden kamień i jeden kamień to dwa kamienie, jeden wielbłąd i jeden wielbłąd to dwa wielbłądy, itp., doprowadził do uogólnienia, że $1+1=2$, a w konsekwencji do stworzenia arytmetyki" ${ }^{\prime 4}$. Mimo pojawiania się nowych odkryć empirycznych wzorzec, w przeciwieństwie do modelu, pozostaje nadal aktualny. Systemy w ujęciu Mazurowskim składają się z organów mających charakter funkcjonalny, a nie członów o charakterze strukturalnym. Marian Mazur dążył do możliwie najdalej posuniętego uproszczenia warstwy matematycznej i podchodził z pobłażaniem do humanistów, którzy zachłysnęli się matematyką, traktowali ją na sposób magiczny i starali się „na siłę” matematyzować swoje wywody, aby przydać im powagi i wiarygodności. Skoro w kontekście Wienera i Kiszy wspominano o socjologii nauki, to zupełnie na marginesie można w tym miejscu wspomnieć, iż Mazur był wielkim orędownikiem radykalnego odbiurokratyzowania nauki, co wyraził między innymi w książce Historia naturalna polskiego naukowca ${ }^{85}$. To genialne dziełko z zakresu socjologii nauki przysporzyło mu wielu wrogów.

Mazur niewiele miejsca poświęcił rozważaniom stricte prawniczym. W pewnym sensie za wkład do szeroko rozumianej problematyki prawniczej można zaliczyć jego ,pracę paszportową" - cytowaną już książkę Cybernetyka a zarządzanie. Choć napisanie tej książki zostało postawione jako warunek otrzymania paszportu i przeznaczona była ona na użytek wewnętrzny MSW, to zawiera znikomą liczbę przykładów, odniesień i rozważań „resortowych”. Ponadto Marian Mazur zawarł w swoich dziełach sporą liczbę krótkich odniesień do tematów prawniczych. Odniesienia te mają bardzo zróżnicowany ciężar gatunkowy - od prywatnych, subiektywnych opinii i anegdot, poprzez obrazowanie pewnych prawideł cybernetycznych na przykładach prawniczych aż do cennych postulatów merytorycznych. Przykładem tych ostatnich może być następujący fragment: „Z tego punktu widzenia dość niefortunne jest sądowe wyrażenie kara za fatszywe zeznania - powinno by się mówić raczej o karze za kłamliwe zeznania, gdyż źródłem fałszywych zeznań mogą być również omyłki, złudzenia itp. okoliczności, których subiektywności zeznający nie zaprzecza"86.

Na tematy prawnicze wypowiadało się wielu Mazurystów. Pracujący do 1993 roku na Akademii Spraw Wewnętrznych Zbigniew Franciszek Zaniewski wykorzystywał Mazurowską teorię systemów autonomicznych i cybernetyczną teorię charakteru na gruncie prawniczym, przede wszystkim w zakresie kryminologii. ${ }^{87}$ Maciej Węgrzyn, starszy inspektor Państwowej Inspekcji Pracy w stanie spoczynku

${ }^{84}$ Ibidem, s. 14.

${ }^{85}$ M. Mazur, Historia naturalna polskiego naukowca, Warszawa 1970.

${ }^{86}$ M. Mazur, Jakościowa teoria informacji, op.cit., s. 187.

87 Przykładowo: Z. Zaniewski, W.W. Szczęsny, Cybernetyczne modelowanie pamięci a proces resocjalizacji, „Zeszyty Naukowe Akademii Spraw Wewnętrznych” nr 47, Warszawa 1987. 
oraz autor licznych popularnonaukowych i kilku naukowych publikacji cybernetycznych ${ }^{88}$, stosował Mazurowskie koncepcje przy rozwiązywaniu konfliktów w zakładach pracy i przy prowadzeniu dochodzeń w sprawach wypadków. Opowiadał się on przeciwko „wyrabianiu norm” nakładanych kar i rozrostowi biurokracji oraz za ograniczeniem ingerencji do niezbędnego minimum, co spotykało się z oporem przełożonych zarówno w PRL, jak i ponoć w kapitalistycznej III RP. Pokaźną część swojego bogatego dorobku naukowego poświęcił problematyce prawniczej Józef Maria Stefan Ferdynand Kossecki. ${ }^{89}$ Sporo uwagi zagadnieniom prawniczym poświęcił on również $\mathrm{w}$ ramach działalności popularyzatorskiej, prowadzonych przez siebie szkoleń oraz w działalności praktycznej. ${ }^{90}$ Wkład Józefa Kosseckiego

88 Przykładowo: M. Węgrzyn, Sytuacje konfliktowe w procesie produkcji, „Postępy Cybernetyki” nr (10) 2, 1987.

${ }^{89}$ Kossecki stworzył kompleksową teorię norm (oraz odpowiadających im motywacji) - od najbardziej informacyjnych (poznawczych ścisłych) do najbardziej energetycznych (witalnych). Normy prawne uznał za odmianę norm konstytutywnych (J. Kossecki, Cybernetyka kultury, Warszawa 1974, s. 111-117). Normy konstytutywne dzielą się na normy ideologiczne, etyczne i prawne. Te ostatnie mają przewagę czynnika energetycznego, zaś wcześniejsze są w przeważającej części informacyjne. Kossecki rozwijał to w swoich kolejnych dziełach (J. Kossecki, Cybernetyka społeczna, wydanie II poprawione i rozszerzone, Warszawa 1981 s. 96-101). Opisywał także funkcjonowanie różnych systemów w zależności od tego, jaki typ motywacji w nich dominuje i czy są stacjonarne (nastawione na zachowanie obecnego stanu) czy dynamiczne (nastawione na rozwój). Opisał więc również system stacjonarny (ibidem, s. 343-352) i dynamiczny (ibidem, s. 352-358) z przewagą motywacji prawnych. Pole osobowości, które Mazur wiązał jedynie z dynamizmem charakteru (o dynamizmie wspomniane zostanie w dalszej części artykułu), rozszerzył także na systemy motywacji (J. Kossecki, Tajniki sterowania ludźmi, Warszawa 1984, s. 102-115). Kossecki opisywał, jak racjonalnie dbać o praworządność w społeczeństwach, które posiadają niskie motywacje prawne, a do takich od wieków zalicza się polskie społeczeństwo. Bezpośrednie forsowanie norm prawnych prowadzi do osłabienia motywacji etycznych i zwiększenia pozycji motywacji witalnych (te dwa ostatnie typy motywacji od lat walczą w polskim społeczeństwie o dominację). Należy doprowadzić do możliwie najpełniejszej zgodności prawa z etyką, uzasadniać zasadami etyki potrzebę przestrzegania prawa oraz dbać o poziom moralny funkcjonariuszy odpowiadających za obronę porządku prawnego. Zawarte w Kosseckiańskiej Metacybernetyce koncepcje podziału twierdzeń i dowodów mogą znaleźć zastosowanie również na gruncie prawniczym (co pokazano chociażby w przywoływanej rozprawie doktorskiej M.H. Górnego Optymalizacja czynności kryminalistycznych, s. 170-174). Najbardziej kompleksowo do sprawy wykorzystania narzędzi cybernetycznych w praktyce prawniczej podszedł Kossecki w Elementach nowoczesnej wiedzy o sterowaniu ludźmi (J. Kossecki, Elementy nowoczesnej wiedzy o sterowaniu ludźmi. Socjotechnika, socjocybernetyka, psychocybernetyka. Skrypt dla oficerów Policji, Kielce 2001). Magistrantami Kosseckiego było wówczas wielu policjantów i skrypt powstał pod wpływem wszechstronnego zbadania potrzeb praktyki służbowej, choć nie zabrakło w nim również solidnych podstaw teoretycznych.

${ }^{90}$ Józef Kossecki był współzałożycielem Ligi Narodowo-Demokratycznej - pierwszej konspiracyjnej organizacji antykomunistycznej o charakterze cywilnym w PRL - i autorem jej programu. W ramach LND organizował szkolenia, na których m.in. propagował koncepcje prawnicze Leona Petrażyckiego oraz cywilizacyjne Feliksa Konecznego (który uznawał prymat etyki nad prawem pozytywnym w polskiej kulturze), a także rozmaite postulaty w sferze prawej jak chociażby 
do nauk prawnych i jego poglądy na zagadnienia prawnicze nadają się na osobne opracowania, zarówno merytoryczne (wykorzystaniu koncepcji Kosseckiego poświęcono sporo miejsca w jak dotychczas nieopublikowanej rozprawie doktorskiej, a także w kilku innych tekstach ${ }^{91}$ autora niniejszego artykułu), jak i antykwaryczne. W niniejszym tekście nie ma niestety miejsca na rozwijanie tych kwestii. W literaturze cybernetycznej, nie tylko tej należącej do nurtu Mazurowskiego, można natrafić nieraz na przykłady możliwych zastosowań metod wywodzących się z cybernetyki

przywrócenie instytucji sędziów śledczych czy walka ze zjawiskiem aresztów wydobywczych. Po rozbiciu struktur warszawskich LND i odbyciu kar pozbawienia wolności przez niektórych liderów (w tym przez Kosseckiego), kierownictwo zadecydowało, iż LND winna skupić się na działalności przykrywkowej, a jej członkowie występować pod szyldami różnych oficjalnie działających organizacji. Po zatarciu skazania Kossecki wstąpił do PZPR i swoje poglądy i koncepcje prawnicze wygłaszał również jako lektor partyjny, dodając do nich także elementy cybernetyczne. W ramach Towarzystwa Kultury Moralnej działał razem z m.in. Januszem Korwin-Mikkem na rzecz zmian prawnych mających na celu walkę z procederem spędzania płodów. Do promocji swoich postulatów i koncepcji prawniczych wykorzystywał stanowisko sekretarza ds. propagandy Zjednoczenia Patriotycznego „Grunwald”. Jako dziennikarz i publicysta popularyzował swoje poglądy i koncepcje prawnicze na łamach prasy ogólnopolskiej, regionalnej, partyjnej, resortowej, branżowej i organizacyjnej. Kwestie prawnicze poruszał również w ramach Polskiego Towarzystwa Cybernetycznego, którego był członkiem. Będąc w latach 1986-1988 szefem szkolenia warszawskiego ORMO, oparł kurs na przedwojennych wytycznych szkoleniowych Policji Państwowej, koncepcjach Pawła Horoszowskiego - klasyka polskiej kryminalistyki oraz na osiągnięciach polskiej szkoły cybernetyki. Organizował wiele akcji bezpośrednich ORMO, głównie wymierzonych w meliny oraz w skorumpowanych milicjantów, często dowodził takimi akcjami. W roku akademickim 1989/1990 prowadził w legionowskiej filii Wyższej Szkoły MSW zajęcia z cybernetyki społecznej i statystyki. W okresie od lipca do września 1990 prowadził tam szkolenie dla oficerów policji z wykorzystania nowoczesnych metod, w tym cybernetycznych, do walki z przestępczością. Na okres zimowy zaplanowany był kurs dla oficerów policji z wykorzystania metod cybernetycznych w zwalczaniu przestępczości zorganizowanej. Kurs zimowy nie odbył się po interwencji ministra Kozłowskiego, który stwierdził, że w Polsce nie ma problemu przestępczości zorganizowanej. NB! Przez pewien czas z ministrem Kozłowskim współpracował wspominany wcześniej Zbigniew Zaniewski. Józef Kossecki, jako zastępca, a później następca Stanisława Tymińskiego na funkcji przewodniczącego Partii „X”, zajmował się na gruncie programowym wieloma zagadnieniami prawniczymi, przykładowo ogłosił projekt zmian w ustawie o Policji, który był konsultowany ze Związkiem Zawodowym Policjantów. Sporo miejsca zagadnieniom prawniczym poświęcał w prowadzonych do końca życia społecznie szkoleniach, wykładach otwartych i wystąpieniach internetowych; zwłaszcza w ramach założonej przez siebie nieformalnej Narodowej Akademii Informacyjnej (strona NAI: www.socjocybernetyka.pl).

${ }_{91}$ Przykładowo: M.H. Górny, Psychocybernetyka w pracy policji-zarys zagadnienia, „Kwartalnik Prawno-kryminalistyczny” nr 5, 2010; M.H. Górny, Optymalizacja polityki kryminalnej część ogólna, artykuł przyjęty do druku w „Pro Fide, Rege et Lege”. W swojej pracy magisterskiej (M.H. Górny, Optymalizacja badań materiatu dowodowego, napisana pod kierunkiem prof. dra hab. nauk prawnych i mgr chemii Mirosława Owoca niepublikowana praca magisterska obroniona 1 czerwca 2009 roku na Wydziale Prawa i Administracji Uniwersytetu im. Adama Mickiewicza w Poznaniu) wykorzystuje autor teorie Mariana Mazura oraz postuluje odwołanie się w dalszej działalności naukowej również do Józefa Kosseckiego. 
lub badań operacyjnych do walki z przypadkami naruszenia porządku prawnego. ${ }^{92}$ Ciekawostkę stanowi artykuł Janusza Ryszarda Korwin-Mikkego. ${ }^{93}$

Dorobek Mariana Mazura wykorzystywał zarówno w swojej działalności naukowej, jak i dydaktycznej ${ }^{94}$ wybitny kryminalistyk Mirosław Owoc. Zajmował się on przede wszystkim techniką kryminalistyczną, ale nie zabrakło u niego, zwłaszcza w artykułach, w których przywoływany był dorobek Mazura, rozważań z zakresu teorii i metodologii kryminalistyki. Dysertacja habilitacyjna Owoca stanowi wczesny (jak się zdaje najwcześniejszy) przykład dostrzeżenia, docenienia i wykorzystania jakościowej teorii informacji na gruncie kryminalistyki. ${ }^{95}$ Jak słusznie zauważył Mirosław Owoc - ,jedynym jak dotąd autorem, który podjął uwieńczoną sukcesem próbę uchwycenia istoty informacji, jest polski uczony Marian Mazur"96. Jakościową teorię informacji wykorzystywał Owoc również w późniejszych publikacjach. ${ }^{97}$ Owoc doceniał też Mazurowską cybernetyczną teorię decyzji, jego zdaniem Mazur „omawia w sposób niezrów-

92 Przykładowo: J. Kazimierczak, Teoria gier w cybernetyce, Warszawa 1973. Na stronach 66-71 opisano tam wykorzystanie programowania sieciowego i strategii przy pościgu policyjnym za uciekającą samochodem grupą sprawców zdarzenia kryminalnego.

93 J. Korwin-Mikke, Socjocybernetyka - problemy i metody, „Postępy Cybernetyki” nr 4, rok 3, 1980. Wbrew tytułowi, w tekście nie ma niemal nic na temat metod. Znajdują się tu za to, poza anegdotami niezwiązanymi z tematem artykułu, rozważania na temat problemów oraz odniesienie do zagadnień prawniczych. Na stronie 41 Korwin-Mikke zwraca uwagę na problemy związane ze słabym obsadzeniem cybernetyki społecznej i związanego z tym zagrożenia nieistnieniem dostatecznej krytyki wewnętrznej. Na stronach 42 i 43 rozważany jest problem informacji dostarczanych do sądów. Korwin-Mikke usiłował podkreślić dobitnie, że przeszkodą w wydaniu sprawiedliwego wyroku może być nie tylko niedomiar informacji, ale również ich nadmiar - możliwość przeoczenia informacji zbyt często powtarzanych oraz zagrożenie brakiem obiektywizmu sędziego po dostarczeniu mu informacji, które do rozstrzygnięcia sprawy nie są konieczne, a mogą go nastawić uczuciowo do uczestników postępowania (co przedstawione zostało jako potencjalna sprzeczność między interesami poszczególnych sędziów a interesami wymiaru sprawiedliwości jako całości). Janusz Korwin-Mikke polemizuje też z niektórymi twierdzeniami Mariana Mazura i Józefa Kosseckiego. Jest to niestety krytyka z gruntu błędna, jako że Korwin-Mikke wychodzi od zupełnie innej definicji homeostatu, a następnie ocenia wywody Mazura i Kosseckiego tak, jak gdyby obaj ci autorzy bazowali na Korwinowskiej definicji. U Mazura homeostat jest organem odpowiedzialnym w ramach danego systemu za homeostazę, Korwin-Mikke używa terminu homeostat na określenie całego sytemu, który jest zdolny do homeostazy.

${ }_{94}$ Podstawy Mazurowskiej cybernetycznej teorii charakterów omawiał Owoc zarówno na wykładach z kryminalistyki, jak i na prowadzonych przez siebie seminariach magisterskich. Właśnie na wykładzie z kryminalistyki autor niniejszego artykułu, jeszcze jako student, miał okazję po raz pierwszy usłyszeć o Marianie Mazurze.

${ }_{95}$ M. Owoc, Kryminalistyczne znaczenie fotografii barwnej w ujęciu teorii informacji, Poznań 1973.

${ }^{96}$ Ibidem, s. 10.

97 Przykładowo: M. Owoc, Cybernetyczny model ekspertyzy [w:] Wybrane zagadnienia teorii i metodologii kryminalistyki pod red. J. Widackiego, Katowice 1983. 
nanie wszechstronny teorię podejmowania decyzji [...]"98. Owoc nie jest jednak jedynym kryminalistykiem odwołującym się do Mazura. Jerzy Konieczny przytacza różnice, jakie zdaniem Mazura zachodzą między naukowcami a doktrynerami. ${ }^{99}$ Współczesnym przykładem zainteresowania organów śledczych osiągnięciami polskiej szkoły cybernetyki może być artykuł Macieja Aleksandra Kędzierskiego zamieszczony w oficjalnym publikatorze ABW, w którym to artykule cytowane są zresztą wielokrotnie publikacje Mariana Mazura, Józefa Kosseckiego oraz Macieja Henryka Górnego. ${ }^{100}$ Wykorzystywaniem i rozwijaniem dorobku polskiej szkoły cybernetyki zajmuje się autor niniejszego artykułu, ale, rzecz jasna, nie miejsce po temu, aby się nad tym rozwodzić. Jednak wspomnieć można jedynie, iż autor skupia się na zagadnieniach taktycznych, metodologicznych i teoretycznych.

Odwołania do dorobku Mazura pojawiają się też w nowszych publikacjach dotyczących teorii prawa i informatyki prawniczej. Przykładem jest artykuł Pojęcie informacji w naukach teoretycznoprawnych. ${ }^{101} \mathrm{~W}$ tekście tym odwołania do ,jakościowej teorii informacji” Mazura są częste i mają charakter aprobujący (zawarto tam nawet wyrazy ubolewania z powodu zbyt słabego rozpowszechnienia się jakościowej teorii informacji), celem zaś tekstu jest uchwycenie istoty informacji. W tym kontekście dziwi brak przytoczenia Mazurowskiej definicji informacji, tym bardziej że rozmiary artykułu spokojnie pozwalały na jej przytoczenie i na wyjaśnianie użytych w niej terminów.

Zdarzają się też teksty prawnicze odwołujące się do dorobku Mazura, które są kuriozalne. Przykładem może być artykuł Mikkego. ${ }^{102} \mathrm{Z}$ tekstu Mikkego bije zachwyt w stosunku do dorobku Mariana Mazura, co tylko zwiększa szkodliwość tego tekstu z punktu widzenia cybernetyki. Pomijając dość prymitywne aluzje

${ }_{98}$ M. Owoc, Naukowe metody przewidywania przyszłości [w:] Niekonwencjonalne metody rozpoznawczo-wykrywacze, Materiały Sympozjum Naukowego Szczecin-Pobierowo 24-26 IV 2003 pod red. K. Sławika i M.A. Wasilewskiej, Szczecin 2003, s. 42. Mazurowską teorię decyzji omawiał Owoc już wcześniej - zob. Od intuicji do rachunku prawdopodobieństwa i z powrotem, Materiały VIII Sympozjum Metodologii Kryminalistyki i Nauk Pokrewnych, Uniwersytet Śląski Wydział Prawa i Administracji Katedra Kryminalistyki, Katowice 1988, s. 68 i nn.

99 J. Konieczny, Metodologiczna charakterystyka kryminalistyki, Katowice 1984, przypis nr 32 zaczynający się na stronie 18, a kończący na 19.

${ }_{100}$ M.A. Kędzierski, Zastosowanie rozwinięcia teorii układów samodzielnych na potrzeby typowania przywództwa organizacji przestępczej - analiza psychocybernetyczna, „Przegląd Bezpieczeństwa Wewnętrznego" nr 9, 2013.

${ }^{101}$ M. Kłodawski, Pojęcie informacji w naukach teoretycznoprawnych [w:] Rola informatyki $w$ naukach ekonomicznych $i$ społecznych. Innowacje $i$ implikacje interdyscyplinarne pod redakcją Z.E. Zielińskiego, tom 2/2012, Kielce 2012 [za:] http://depot.ceon.pl/bitstream/handle/123456789/316/Maciej_Klodawski_-_Pojecie_informacji_w_naukach_teoretycznoprawnych. pdf? sequence=1\&isAllowed=y [dostęp: $18.02 .201 \overline{7}$.

102 S. Mikke, Prawo w Cyberlandii, ,Palestra” 11-12/2005 [za:] http://palestra.pl/old/index. php?go=artykul\&id=1807 [dostęp: 18.02.2017]. 
do ówczesnej sytuacji politycznej, konstruowane z użyciem wielkich kwantyfikatorów i metody „nie stawiania kropki nad i” (formułowane zaraz po wyborach przez redaktora naczelnego oficjalnego organu prasowego adwokatury), jest to jednak tekst do pewnego stopnia niezwykle symptomatyczny dla osób pobieżnie zaznajomionych z twórczością Mazura, zwłaszcza tych, których kontakt z cybernetyką ograniczył się do książki Mazura Cybernetyka i charakter. Wiele osób, które zetknęly się z dorobkiem Mazura ma tendencje do wyolbrzymiania znaczenia dynamizmu charakteru i pomniejszania innych wyszczególnionych przez Mazura parametrów oraz do ignorowania parametrów wyszczególnionych przez następców Mazura. Dynamizm charakteru jest to logarytm stosunku współczynnika rozbudowy do współczynnika starzenia się systemu autonomicznego. ${ }^{103}$ Dynamizm zmienia się naturalnie wraz $\mathrm{z}$ upływem czasu, nieuchronnie w jedną stronę - od wartości najbardziej dodatnich (przewagi rozbudowy nad starzeniem) do ujemnych. W tempie tych zmian występują różnice zarówno jednostkowe, jak i grupowe. Rozbudowie towarzyszy zwiększenie zapotrzebowania na moc jałową, to prowadzi do zwiększenia odsetka mocy całkowitej systemu, która jest przeznaczana na moc jałową, to może prowadzić do zastępowania niedoborów mocy fizjologicznej mocą socjologiczną. Im bardziej dodatni dynamizm, tym większa tendencja do rozpraszania; im bardziej ujemny, tym większa tendencja do gromadzenia. ${ }^{104}$ Mazur wprowadził umowny (zmiany dynamizmu nie mają charakteru skokowego) podział na pięć klas dynamizmu (od najbardziej dodatniego): egzodynamik, którego cechuje ogromna przewaga rozpraszania and gromadzeniem; egzostatyk, którego cechuje znacząca przewaga rozpraszania nad gromadzeniem; statyk, którego cechuje względna równowaga gromadzenia i rozpraszania; endostatyk, którego cechuje znacząca przewaga gromadzenia nad rozpraszaniem; endodynamik, którego cechuje ogromna przewaga gromadzenia nad rozpraszaniem. ${ }^{105}$ Mikke dość obszernie, jak na niewielkie ramy swojego artykułu, omawia koncepcje Mazura. Jednakże wymienia tylko dynamizm charakteru, nie wspominając o innych wymienionych i opisanych w Cybernetyce $i$ charakterze parametrach, do tego nie przytacza definicji dynamizmu, ale sprowadza go do zastępowania mocy fizjologicznej mocą socjologiczną (co jest jednym ze skutków, a nie istotą dynamizmu). W artykule Mikkego można zaobserwować przejawy moralnego wartościowania ze względu na dynamizm - osoby, które wcześniej zostają endodynamikami dążą do władzy, wśród nich wymienia Mikke Juliusza

${ }^{103}$ M. Mazur, Cybernetyka i charakter, op.cit., s. 290.

104 Ibidem, s. 291-298.

105 Ibidem, s. 300. Mazur pisał dosłownie, że egzodynamik „wszystko” rozprasza, statyk tyle rozprasza, ile gromadzi, a endodynamik tylko gromadzi. Jest to opis mający charakter ilustracyjny, potoczny. Należy to uznać za zbytnie uroszczenie, które wielu czytelników (w tym i omawiany Mikke) Cybernetyki i charakteru przyjęło dosłownie. 
Cezara, Bolesława Chrobrego i polityków „wiadomej” formacji (,zrezygnujemy z nazwisk, i tym razem wszystko przecież jasne"). Mazur stanowczo odżegnywał się od wartościowania moralnego parametrów charakteru. Uważał, że dają one pewne predyspozycje, które mogą być zarówno dobrze, jak i źle wykorzystane.

Mikke wspomina spotkanie z jednym z Mazurystów, którego zapytał ,jak ocenia, po kilkugodzinnej rozmowie mój dynamizm. Usłyszałem, co następuje: Jest Pan egzostatykiem. [...] Zbliża się Pan jednak nieuchronnie do statyzmu, czyli równowagi energetycznej. Od tamtej rozmowy [...] minęło dwadzieścia lat. Ale jakoś nie odczuwam spadku dynamizmu. Zatem życzę tego samego, dobrego dynamizmu Wszystkim, którzy dotrwali do tego miejsca". Zmiany dynamizmu, choć przebiegają w różnym tempie, są jednak nieuchronne. Nie są one jednak tożsame ze spadkiem kondycji lub samopoczucia. $Z$ dynamizmem związane są nadmiar lub niedomiar mocy dla homeostatu (,z punktu widzenia” homeostatu). ${ }^{106}$ Endodynamik może posiadać znacznie więcej mocy niż egzodynamik, po prostu proporcjonalnie większą część jego mocy całkowitej stanowi moc jałowa, ale to, co zostanie i tak może przewyższać możliwości konkretnego egzodynamika. Mazur podał szereg twierdzeń dotyczących tendencji, jakim sprzyjają poszczególne klasy dynamizmu. ${ }^{107}$ Twierdzenia te zawierają szereg błędów, ale największym ich mankamentem jest to, że Mazur nie wyjaśnił wyraźnie, iż są to tylko uwarunkowania sprzyjające pewnym zjawiskom, a nie cechy immanentne poszczególnych systemów przez cały czas ich przynależności do danej klasy dynamizmu. Tendencje te nakładają się na inne, wynikające z innych parametrów charakteru i występują w uwikłaniu z wyobrażeniami, w formach, jakie są możliwe w danym otoczeniu. Niestety, przykłady wymienianie w ramach twierdzeń są często traktowane jak cechy bezwzględnie przypisane do danej klasy dynamizmu (ewentualnie uważa się, że dany osobnik należy do tej klasy dynamizmu, której przykładowych objawów zaobserwowano najwięcej, a pozostałe przykłady to przejawy szerokości charakteru). To samo dotyczy twierdzenia o poczuciu prawa ${ }^{108}$, które przywoływał Mikke. Mazur podawał, że egzodynamików cechuje pozaprawność, egzostatyków uchylanie się od prawa krzywdzącego, statyków legalizm, endostatyków omijanie prawa utrudniającego działalność, endodynamików ponadprawność i instrumentalne podejście do prawa. Mikke przyjmuje ten opis stosunku do prawa, czyni jedynie zastrzeżenie, że nie dotyczy to sytuacji, gdy system prawny jest zbrodniczy i w związku z tym jakaś grupa go nie uznaje (jako przykład, niezbyt adekwatny, podaje chrześcijan w Imperium Rzymskim). Tymczasem Mazurowskie przypisanie cech stosunku do prawa jest zasadne tylko jeżeli poszczególne osoby w ogóle posiadają znajomość przepisów prawa, posiadają wystarczające

\footnotetext{
106 Ibidem, s. 295.

107 Ibidem, s. 298-363.

108 Ibidem, s. 310, 311.
} 
przymioty umysłowe, aby móc dokonać wyborów zgodnych z prawem (rozpoznać w stosownym czasie, co jest zgodne z prawem, a co nie), mają wystarczająco silne motywacje prawne i uznają ten konkretny system prawny.

Mikke postuluje badania dynamizmu sędziów. Można się domyślić, że chodziło Mikkemu o eliminację osób o skrajnych dynamizmach. Ale to nie tylko oznaczałoby, że sędziami mogą zostać osoby o określonych dynamizmach, znajdujące się w określonym przedziale wiekowym, ale również, iż wielu sędziów winno kończyć kariery bez własnej winy po osiągnięciu niepożądanego dynamizmu, jeszcze przed osiągnięciem normalnego wieku do przejścia w stan spoczynku. Nie wiadomo też, jak miałby wyglądać „krótki test” badający dynamizm na podstawie kilku cech, w tym ubioru, co postulował Mikke. Podczas procesu rekrutacyjnego stroje kandydatów na sędziów są na ogół sformalizowane. Po ujawnieniu istnienia „krótkiego testu” na dynamizm stopień formalizacji i ujednolicenia ubioru wśród kandydatów na sędziów uległby z pewnością zwiększeniu. Mazur pisał o skłonnościach egzodynamików wręcz do nagości, co tylko pokazuje jak wielką ostrożność należy zachować przy wykorzystywaniu twierdzeń o skłonnościach, którym sprzyjają poszczególne klasy dynamizmu. Pozwolono sobie na dłuższe omówienie tego krótkiego tekstu ze względu na jego symptomatyczność i potencjalną szkodliwość. Zbyt swobodne, a nawet dowolne, traktowanie cybernetyki i proste przenoszenie uproszczonych koncepcji cybernetycznych na grunt prawniczy może spowodować na tym gruncie poważne szkody, a przy okazji doprowadzić do ośmieszenia cybernetyki.

Niektórzy patrzą na cybernetykę jak na zagrożenie o wymiarze apokaliptycznym: „,cybernetyzacja polityki i prawa polega na przenoszeniu ich do cyberprzestrzeni i wkraczaniu na te pola cybernetyki społecznej. Cybernetyka społeczna stosowana do cybernetycznych społeczności zyskuje wprost nieograniczone możliwości sterowania, instrumentalizacji i uprzedmiotowienia. Cybernetyka jako technika sterowania społecznego i cyberprzestrzeń jako środowisko życia społecznego wyłączają autentyczność i autonomię w dziedzinie polityki i prawa. Tak polityka, jak i prawo stają się zależne od ukrytych oddziaływań infrastrukturalnych ${ }^{27 " 109}$. Przypis 27, zawarty między ostatnim słowem cytowanego fragmentu a kropką, zawiera następujące odwołanie: „Por. J. Kossecki, Cybernetyczna analiza systemów i procesów społecznych, Kielce 1996". Niestety, trudno odgadnąć, czego to odwołanie ma konkretnie dotyczyć - czy Janowski sugeruje, że Kossecki wyrażał tego typu obawy (co byłoby niedorzeczne - dostrzeże to łatwo każdy, kto zapoznał się z dorobkiem Kosseckiego), czy też zarzuca Kosseckiemu, iż swoją książką przyczynił się był do rzekomego urzeczywistnienia tychże obaw. Cały

109 J. Janowski, Globalna cyberkultura polityki i prawa [w:] Tendencje rozwojowe myśli politycznej i prawnej pod red. M. Maciejewskiego, M. Marszała i M. Sadowskiego, Wrocław 2014, s. 323 [za:] http://www.repozytorium.uni.wroc.pl/Content/46512/23_Jacek_Janowski.pdf . 
tekst Janowskiego cierpi z powodu maniery dodawania przedrostka „cyber” do wszystkiego, co wiąże się z zagadnieniami internetowymi lub komputerowymi, przez co trudno ocenić zawartość cybernetyki w tej cybernetyce. Janowski nie wyjaśnia w swoim artykule, co rozumie pod takimi pojęciami jak ,autonomia” czy „autentyczność” (to ostatnie jest zaś w tym kontekście szczególnie frapujące). Próżno szukać też wyjaśnienia, w jaki sposób cybernetyka, działająca wspólnie i w porozumieniu z równie złowrogą cyberprzestrzenią, „wyłączają” (sic! - nie „ograniczają”, nie „utrudniają wystąpienie”, lecz całkowicie „wyłączająa”) autonomię i autentyczność oraz dlaczego oferowane przez cybernetykę możliwości instrumentalizacji i uprzedmiotowienia są „nieograniczone” (a nie jedynie „ogromne”, „poszerzone w stosunku do...” etc.). Polemizowanie z tekstem Janowskiego to wchodzenie na grunt merytoryczny, tymczasem artykuł niniejszy ma być w założeniu nade wszystko antykwaryczny (co kilkukrotnie zaznaczano). Można jednak nadmienić, iż niektórzy przesiąkają poglądami Janowskiego. ${ }^{110}$ W tym miejscu wypada jednak oddać głos Kosseckiemu z jego ,inkryminowanego" tekstu, w którym stwierdził, iż cybernetyka „bada metody manipulacji, a jej

110 T. Marzec, Co może dać nauce prawa cybernetyka, a czego da nie może? [w:] „Studia Iuridica Toruniensia" Tom XVII, 2015 za: http://dx.doi.org/10.12775/SIT.2015.021 [dostęp: 21 II 2017]. Nie licząc samego krótkiego wprowadzenia, pierwsza połowa tekstu poświęcona jest filozofującym, a nawet teologizującym rozważaniom na temat kondycji ludzkości. Nie brakuje w tej części aprobujących odwołań do tekstów Janowskiego - tekstów, jak należy sądzić z tychże odwołań, utrzymanych w podobnej poetyce, co cytowany w niniejszym artykule tekst Globalna cyberkultura polityki i prawa. W drugiej części Marzec skupia się na dorobku Mariana Mazura. Opisana zostaje Mazurowska teoria systemu autonomicznego, a następnie propozycja jej wykorzystania na gruncie prawa - jest to cybernetyzujący opis procesu karnego i polityki karnej, w którym to opisie poszczególnym podmiotom przypisano rolę organów systemu autonomicznego (systemem autonomicznym jest w tych rozważaniach państwo). Opis jest mocno naciągany. Aż prosiłoby się o odwołanie do innych wzorców systemu niż autonomiczny. Ponadto pojawiają się w tekście Marca odwołania do krytycznych uwag Wienera na temat jemu współczesnej polityki karnej. Gdyby tylko tyle cybernetyka mogła dać prawu, byłaby ona tylko mało znaczącą ciekawostką. Naturalnie, polemizowanie z tezami artykułu Marca wykracza poza ramy niniejszego artykułu. Wypada jednak zwrócić uwagę na wyzierające z tekstu niezrozumienie założeń i możliwości cybernetyki. Marzec kilkukrotnie podkreślał, że cybernetyka nie uwzględnia nieracjonalnych zachowań człowieka i jego uczuć - przykładowo: „Nieracjonalność człowieka, ignorowana przez cybernetykę, przejawia się także w tym, że gros celów wyznaczających działania człowieka pozostaje w sferze nieuświadomionej, co wiemy dzięki psychoanalizie" (ibidem, s. 129). Jest to oczywista bzdura, zwłaszcza w odniesieniu do koncepcji Mariana Mazura, a to one stanowiły podstawę rozważań w drugiej, „właściwej”, części artykułu Marca. Mazur dążył do poznania wszelkich możliwych typów dążeń i zachowań, także tych nieracjonalnych; od zakładania racjonalizmu stanowczo się odżegnywał. Podobnie czynił Kossecki, również przez Marca przywoływany. O tym, że cybernetyka może na gruncie prawa pomóc w poznaniu rzeczywistych (często nieracjonalnych) zachowań w sferze prawnej świadczą liczne prace polskich prawników zajmujących się cybernetyką. Niestety, Marzec żadnej z tych prac nie przywołał. Jedyne przywołane przez niego teksty prawnicze, w których poruszono zagadnienia cybernetyczne, to teksty Janowskiego. 
wyniki mogą być wykorzystywane zarówno do manipulowania ludźmi, jak i do obrony przed manipulacją"111. Sam Kossecki wierzył, że poprzez publikowanie i rozpowszechnianie naukowych, popularnonaukowych i publicystycznych tekstów dotyczących sterowania (w tym i manipulacji, która jest jednym z rodzajów sterowania) przyczyni się do ograniczenia skali manipulacji i poprawy świadomości informacyjnej społeczeństwa. Ogromne nadzieje wiązał w tym względzie z Internetem. Tak zaś o protestach przeciw cybernetyce pisał Ojciec polskiej szkoły cybernetyki: „Wspomniane protesty stawiają sprawę tak, jak gdyby władcy postępowali jak dzieci, które użyją niezwłocznie wszystkiego, co im umożliwi nauka, na którą też spada za to odpowiedzialność"112.

Przede wszystkim należy podkreślić dobitnie, iż cybernetyka jest nauką o sterowaniu, a nie magiczną sztuką sterowania. Jako nauka posiada ona swój bogaty dorobek i oferuje spore możliwości, ale stawia też swoje wymagania i posiada swoje ograniczenia. Będąc nauką badającą istotę działań sterowniczych, w ramach której publikuje się i dyskutuje rozmaite koncepcje, nie stanowi ona takiego zagrożenia jak rozwijane empirycznie i często niejawnie sztuki programowania ludzi na potrzeby reklamy lub służb specjalnych, w których skupia się wysiłki na szybkim osiągnięciu jakiegoś skutku, bez badania istoty zjawisk i dalekosiężnych konsekwencji działań programujących. W świetle powyższego rozwianiu ulec winny zarówno mroczne obawy przed złowieszczymi perspektywami cybernetyki, jak i złudne nadzieje na cudowne i błyskawiczne rozwiązanie wszelkich problemów dzięki posłużeniu się cybernetycznymi środkami. Nie znaczy to wcale, że wobec cybernetyki nie było, nie ma i nie będzie oporów i sprzeciwów. Cybernetyka jest metadziedziną i jako taka może być wykorzystywana zarówno „wewnątrz” poszczególnych dziedzin, jak i na ich styku; można korzystać z narzędzi cybernetycznych jako z czegoś zewnętrznego, jak i pozwolić cybernetyce „przesiąknąć” do istoty nauk prawnych, uprawiać nauki prawnicze na sposób cybernetyczny. Zwłaszcza to ostatnie może budzić obawy i niechęć. Logik Zygmunt Ziembiński pisał, iż ,spora część przedstawicieli szczegółowych nauk prawnych [...] rozważania przez metodologów prowadzone traktuje jako niezrozumiałe dziwaczenia, a wszelkie uwagi krytyczne na temat metodologii nauk prawnych za jeszcze jeden zamach na wątły skądinąd prestiż społeczny tych nauk"113. Mniejszego oporu spodziewać się można przy wykorzystywaniu narzędzi cybernetycznych w kryminalistyce jako w dziedzinie i tak z założenia „pasożytniczej”. Z cybernetyki

111 J. Kossecki, Cybernetyczna analiza systemów i procesów społecznych, Kielce 1996, s. 9.

${ }_{112}$ M. Mazur, Zagadnienie prawdy w nauce, ,Zeszyty Naukowe Stowarzyszenia PAX” nr 1 (30), 1981, s. 92.

${ }_{113}$ Z. Ziembiński, Szkice z metodologii szczegółowych nauk prawnych, Warszawa-Poznań 1983, s. 84 [za:] J. Konieczny, op.cit., s. 11. 
można korzystać zarówno deskryptywnie (do poznawania istoty prawa, do badania rzeczywistego oddziaływania prawa na społeczeństwo etc.), jak i preskryptywnie (do projektowania samego prawa, do optymalizacji procedur decyzyjnych w strukturach podmiotów odpowiedzialnych za egzekwowanie prawa, do kształtowania zachowań społecznych w obszarze prawnym etc. ). Odbywać się to może w pewnych granicach - już Trentowski zaznaczył, iż: „Ludzkość niejest potulnym marmurem i niecierpi na sobie mistrzowskiego dłuta"114.

W historii polskiej cybernetyki prawniczej znaleźć można zarówno takich prawników, którzy poświęcili cybernetyce sporą część swojego dorobku, jak i takich, którzy zajmowali się zagadnieniami cybernetycznymi incydentalnie, na marginesie oraz całą gammę przypadków pośrednich. Można znaleźć artykuły, rozprawy doktorskie, dysertacje habilitacyjne, broszury etc. Dzieła wybitne i kiepskie oraz całą gamę przypadków pośrednich. Publikacje dotyczące zarówno aspektu deskryptywnego, jak i perskryptywnego; filozoficzno- i teoretycznoprawne, jak i kryminalistyczne; korzystające „zewnętrznie” z osiągnięć cybernetyki, jak i wprowadzające cybernetykę do „wnętrza”, do „,istoty” prawa; publikacje bardzo stare (koniec lat 50. i początek 60.), jak i najnowsze. Polskie publikacje z zakresu cybernetyki prawniczej tłumaczone były na różne języki. Polscy cybernetycy i prawnicy utrzymywali ze sobą kontakty - przykładowo: Owoc korespondował z Mazurem, a Kisza oraz autor niniejszego artykułu z Kosseckim. Pomimo iż wybitni polscy prawnicy zajmowali się naukowo cybernetyką, a wybitni polscy cybernetycy zajmowali się naukowo prawem (jedni i drudzy poświęcając tym sprawom nieraz sporo czasu, miejsca i wysiłku), to nie powstał niestety trwały znaczący ruch czy też trend cybernetyki prawniczej.

Choć w niniejszym artykule skupiono się na niekomputerowych przejawach cybernetyki prawniczej, to na koniec warto wspomnieć również o jej komputerowych przejawach. Zagadnienia cybernetyki i informatyki prawniczej poruszane są nieraz łącznie w ramach poszczególnych publikacji. ${ }^{115} \mathrm{Z}$ zagadnieniami wykorzystywania cybernetyki i komputerów na gruncie prawniczym wiąże się problem ewentualnych sztucznych inteligencji, które mogłyby wspierać bądź nawet zastępować człowieka w podejmowaniu pewnych decyzji prawnych. Mazur uważał, iż podstawowym pytaniem, jakie należy zadawać przy rozważaniu kwestii „myślących maszyn”, jest pytanie o to, co to jest myślenie. ${ }^{116} \mathrm{Z}$ kolei Owoc zauważył, że upowszechnieniu i ulepszeniu programów komputerowych często towarzyszy wzrost bezmyślno-

114 F. B. Trentowski, op.cit., s. 190.

115 Przykładowo: M. Owoc, Cyborgizacja ludzi a humanizacja komputerów, „Techniki Komputerowe" nr 1, 2003.

${ }^{116}$ M. Mazur, Cybernetyczne zagadnienia myślenia, „Przegląd Elektrotechniczny” Zeszyt 11, Rok XXXIX, listopad 1963, s. 413. 
ści i lenistwa po stronie ich użytkowników. ${ }^{117}$ Tak czy inaczej projektowane przez Studnickiego w latach 70. XX w. bazy wiadomości prawnych rozpoczęły swoją działalność w latach 90. tegoż wieku. Nad maszynami mającymi automatycznie rozstrzygać spory pracował już Leibnitz (przy czym miał on na względzie przede wszystkim spory między uczonymi). W wielu krajach trwają intensywne prace nad programami mającymi tworzyć projekty orzeczeń. ${ }^{118}$

Cybernetyka prawnicza - zarówno w wydaniu „niemaszynowym”, jak i „maszynowym" - ma na swoim koncie spore osiągnięcia. Mimo oporów, zastrzeżeń, wymagań i ograniczeń stoją przed nią widoki ogromnego rozwoju; to już jednak temat na zupełnie osobny artykuł.

\section{CYBERNETIC OUTLOOK ON LAW - A CONTRIBUTION TO THE HISTORY OF LEGAL CYBERNETICS}

\section{Summary}

Cybernetics is a science devoted to control while law is one of the methods of social control. Cyberneticists' interest in law as well as the interest in cybernetics exhibited by lawyers are both natural. The article describes the history of the development of human thought which finally led to the creation of cybernetics. The paper reaches as far back in time as Ancient Greece where the notions of power and governing were researched scientifically and discussed publically. Conversely, the ancient countries of the Middle East treated the issues of power as magic and they were considered arcane knowledge. Furthermore, the article mentions the cybernetics concepts which Trentowski expressed in his treaty from 1843. Next, it contains a description of Wiener's views on law. Wiener is considered to be the creator of cybernetics as a separate branch of science. Also the reasons behind fighting cybernetics in the USSR were discussed as well as why it was promoted there afterwards. Moreover, publications on the subject of law and cybernetics by three Polish legal theorists (Studnicki, Kisza and Malinowski) were presented. The most important achievements and the main assumptions of the Polish school of cybernetics were delineated. It was first created by Marian Mazur and then further developed by Józef Kossecki. Also the views of some of the Polish cyberneticists on the subject of law were portrayed. The use of cybernetics by Polish forensic scientists was mentioned, especially by Mirosław Owoc. There is also included a reference to the most recent publications on the subject matter of law and cybernetics. Suitable juxtapositions, comparisons and summaries were made. Even though the article concentrates on an antiquarian approach instead of a substantive one, it more than once emphasizes the advantages and disadvantages of each idea.

117 M. Owoc, Komputerowe systemy doradcze a rola biegłego w procesie karnym, „Palestra” nr 1/2, 1994.

118 Przykładowo: R. Rzepka, M. Matsuhara, Y. Kimura, K. Takamaru, H. Shibuki, K. Murakami, Toward Automatic Support For Japanese Lay Judge System - Processing Precedent Factors For Sentencing Trends Discovery [w:] Proceedings of NTCIR-7's MuST track, Dec 2008. 


\section{UN FOCUS CYBERNÉTIQUE SUR LA LOI - UNE CONTRIBUTION À L'HISTOIRE DE LA CYBERNÉTIQUE DE DROIT}

\section{Résumé}

La cybernétique est la science des mécanismes autogouvernés et du contrôle, par contre, la loi constitue l'une des méthodes de contrôle social. L'intérêt des cybernéticiens pour le droit et l'intérêt des juristes pour la cybernétique sont tous deux naturels. L'article montre l'histoire du développement de la pensée humaine qui a finalement conduit à la naissance de la cybernétique. On a profité des expériences de la Grèce antique où les questions de pouvoir et de gouvernement ont été étudiées scientifiquement et publiquement, contrairement aux pays du Proche-Orient ancien où les problèmes de pouvoir étaient traités d'un point de vue magique et considérés comme la science secrète.

On a rappelé des conceptions cybernétiques de Trentowski exposées dans son traité de 1843. Ensuite, on a présenté des opinions sur le droit exprimées par Wiener, connu comme le père fondateur de la cybernétique en tant que domaine scientifique distinct. Les raisons pour combattre et ensuite promouvoir la cybernétique en URSS ont été aussi mentionnées. L'article présente également les publications sur la cybernétique et le droit faites par les théoriciens du droit polonais: Studnicki, Kisza et Malinowski.

Nous avons présenté les plus grandes réalisations et principales hypothèses de l'école polonaise de cybernétique créée par Marian Mazur et développée par Józef Kossecki ainsi que les opinions concernant le droit exprimées par quelques cybernéticiens polonais. Nous avons ensuite mentionné l'utilisation de la cybernétique par des spécialistes polonais en criminalistique, notamment par Mirosław Owoc. Les dernières publications cybernétiques et de droit ont également été remarqués. On a fait des synthèses, comparaisons et résumés pertinents. Bien que l'article se concentre sur les approches fondées sur le trait historique plutôt que sur le contenu, nous nous sommes parfois permis de mettre en évidence les inconvénients et les avantages des concepts particuliers. 